$1-2002$

\title{
Bridging the Digital Divide: Equality in the Information Age
}

Peter K. Yu

peter_yu@msn.com

Follow this and additional works at: https://scholarship.law.tamu.edu/facscholar

Part of the Internet Law Commons, and the Law and Society Commons

\section{Recommended Citation}

Peter K. Yu, Bridging the Digital Divide: Equality in the Information Age, 20 Cardozo Arts \& Ent. L.J. 1 (2002).

Available at: https://scholarship.law.tamu.edu/facscholar/477

This Article is brought to you for free and open access by Texas A\&M Law Scholarship. It has been accepted for inclusion in Faculty Scholarship by an authorized administrator of Texas A\&M Law Scholarship. For more information, please contact aretteen@law.tamu.edu. 


\title{
BRIDGING THE DIGITAL DIVIDE: EQUALITY IN THE INFORMATION AGE
}

\author{
Peter K. Yu*
}

People lack many things: jobs, shelter, food, health care and drinkable water. Today, being cut off from basic telecommunications services is a hardship almost as acute as these other deprivations, and may indeed reduce the chances of finding remedies to them.

$$
\begin{array}{r}
\text {-Kofi Anan, Secretary General, } \\
\text { United Nations }
\end{array}
$$

There is no reason why hundreds of millions of people living in Central Asia, Latin America or Africa should be cut off from the ideas changing the rest of the world-or why these ideas should not be enriched by their local experience-simply because of a lack of readily available cable or satellite technology. The capacity of the Internet-yet to be fully imagined-to eliminate forever the knowledge gap between rich and poor countries may be the single most important determinant of what our world will look like in fifty years. Whether it be linking rural villages in India with one another, health clinics in Kazakhstan to hospitals in Paris, or farmers in Ukraine to commodity markets in Chicago, we have the power to accelerate development by generations.

\section{- James D. Wolfensohn, President, The World Bank Group ${ }^{2}$}

* Acting Assistant Professor of Law, Executive Director, Intellectual Property Law Program \& Deputy Director, Howard M. Squadron Program in Law, Media \& Society, Benjamin N. Cardozo School of Law, Yeshiva University; Research Associate, Programme in Comparative Media Law \& Policy, Centre for Socio-Legal Studies, University of Oxford. The Author would like to thank members of the Cardozo Arts E Entertainment Law Journal and the Communications Law Society, in particular Kimathi Foster and Sarah Warren, for assistance in organizing the Second Squadron Symposium on Internet, Law \& Society, which was held at the Benjamin N. Cardozo School of Law, Yeshiva University on November 15, 2000. This Article benefits from the insights of the participants of the Symposium and contributors to this Symposium Issue, including Andrew Celli, Tracy Cohen, Mark Cooper, Kenneth Dreifach, B. Keith Fulton, Allen Hammond, Mary Keelan, Jack Qiu, and Stefaan Verhulst. The Author also would like to thank Douglas Isenberg, the editor and publisher of GigaLaw.com, for providing a forum for exploring some of the ideas contained in this Article. This Symposium Issue is dedicated to the memory of the late Howard M. Squadron (1926-2001), whose generosity and commitment to legal education had made the Squadron Program possible.

1 Pippa Norris, Digital Divide: Civic Engagement, Information Poverty, and the INTERNET WORLDWIDE 40 (2001).

2 Press Release, James D. Wolfensohn, President, World Bank Group, A Call to Global 
Article 19 of the Universal Declaration of Human Rights provides: "Everyone has the right to freedom of opinion and expression; this right includes freedom to hold opinions without interference or to seek, receive and impart information and ideas through any media and regardless of frontiers." 3 However, not everybody has the ability to seek, receive, and impart information and ideas through the Internet and new communications technologies. Likewise, not everybody has the privilege to fully participate in the information revolution and the New Economy.

The digital revolution has transformed the lives of many, but also has left untouched the lives of many others. As a result, a large segment of the world population misses out on the tremendous political, social, economic, educational, and career opportunities created by the digital revolution. This gap between the information haves and have-nots is commonly referred to as the digital divide. Since the mid-1990s, the digital divide has received considerable attention in international forums, ${ }^{4}$ in presidential debates, ${ }^{5}$ and among corporate leaders. ${ }^{6}$

Action in a Global Economy (Apr. 2000), available at http://www.worldbank.org.ba/news/ 2000/pr-apr0-01.htm.

3 Universal Declaration of Human Rights, G.A. Res. 217, U.N. GAOR, 3d Sess., art. 19 (1948).

4 See, e.g., Joseph Kahn, World Bank Unit to Join in Internet Start-up Finance, N.Y. Times, Feb. 14, 2000, at $\mathrm{C} 6$ (reporting that the World Bank's International Finance Corporation has teamed up with Softbank of Japan to create a fund that will finance Internet start-ups in one hundred less developed countries); Calvin Sims, Group of 8 Pledges to Help Poor Countries, N.Y. Times, July 24, 2000, at A6 (reporting that the G-8 countries "agreed to establish a task force to help developing countries reap the benefits offered by new information technologies"). One journalist described the reaction of the international community:

Since Aug. 1[, 2000], the United Nations has sent 37 high-tech volunteers to countries like Benin, Botswana and Ecuador. The State Department's version, called the Global Technology Corps, began in late 1998 and has sponsored more than 20 projects in Kosovo, Nigeria, Poland and other far-flung locales. Still another project, Net Crops America, focuses only on Latin America and the Caribbean. And in August the Peace Corps began to include information technology among its specialties, sending 10 volunteers to Belize.

Shaila Dewan, Geeks, Proud of the Name, Start a Volunteer Crops, N.Y. Times, Oct. 19, 2000, at G7.

5 For discussions of the different positions concerning education technology taken by Vice President Al Gore and then-Governor George Bush in the 2000 presidential election, see Andy Carvin, Edtech and the Presidential Race, Part 1: George W. Bush's Edtech Proposals, Digital Divide NeTwORk, at http://www.digitaldividenetwork.org/content/stories/index.cfm?key=16 (last visited Dec. 30, 2001); Andy Carvin, Edtech and the Presidential Race, Part 2: Al Gore's Edtech Proposals, Digrtal Divide Network, at http:// www.digitaldividenetwork.org/content/stories/index.cfm?key=18 (last visited Dec. 30, 2001); Katharina Kopp, Searching for the Difference—Gore v. Bush on High Tech Policy, DiciTal DIVIDE NETWORK, at http://www.digitaldividenetwork.org/content/stories/-index.cfm? key=17 (last visited Dec. 30, 2001); Kevin Taglang, Politics and the Digital Divide, Part 1: Vice President Gore and the Democrats, DiGiTAL Divide NETwORK, at http://www.digitaldividenetwork.org/content/stories/index.cfm?key=33 (last visited Dec. 30, 2001).

6 See, e.g., John Markoff, High-Tech Executives Urge Action on World's Digital Divide, N.Y. Times, July 20, 2000, at A6 (reporting that a group of high-tech executives urged the 
During the Clinton Administration, the Department of Commerce conducted four detailed surveys on the digital divide in the United States. ${ }^{7}$ The final report, which was released shortly before the end of the Administration, showed an increasing number of Americans using computers and the Internet. ${ }^{8}$ Between December 1998 and August 2000, the share of households with Internet access rose from $26.2 \%$ to $41.5 \%,{ }^{9}$ while the share of individuals with Internet access rose from $32.7 \%$ to $44.4 \% .^{10}$ By the end of the survey in August 2000, more than half of all American households have computers, ${ }^{11}$ and 116.5 million Americans have Internet access at some locations. ${ }^{12}$

The report also found a rapid increase in Internet access "among most groups of Americans, regardless of income, education, race or ethnicity, location, age, or gender." ${ }^{3}$ For example, the gap in Internet access between households in rural areas and households nationwide has narrowed, ${ }^{14}$ and the disparity in In-

wealthiest nations to help bridge the growing global digital divide); Michel Marriott, Money Is Pledged to Close Digital Divide on Campuses, N.Y. Times, Mar. 16, 2000, at G3 (reporting that Microsoft, IBM, and AT\&T pledged more than \$101 million worth of materials, software, services, training, and financial support for a United Negro College Fund program that aims to improve computer access for students and faculty at historically black colleges and universities).

7 In chronological order, these four surveys are: U.S. Dep'T of Commerce, Falling Through the Net: A Survey of the "Have Nots" in Rural and Urban Americi (1995) [hereinafter FaLling Through THE NET I], available at http://www.ntia.doc.gov/ ntiahome/-fallingthru.html; U.S. Dep'r of Commerce, Falding Through The Net: New Data on the Digital Divide (1998), available at http://www.ntia.doc.gov/ntiahome/net2/ ; U.S. Dep't of Commerce, Falling Through the Net: Defining The Digital Divide (1999) [hereinafter Fal.ung THROUGH THE NET III], available at http://www.ntia.doc.gov/ ntiahome/fttn99/-FTTN.pdf; U.S. Dep'T of Commerce, Falling Through the NeT: Toward Digital Inclusion (2000) [hereinafter Falling Through the Net IV], available at http://search.ntia.doc.gov/pdf/fttn00.pdf.

8 See Falling Through the Net IV, supra note 7 (documenting an increasing level of digital inclusion in the United States).

9 Id. at 1.

10 Id. at 33 .

11 Id. at $1.51 \%$ of American households have computers, and more than $80 \%$ of these households have Internet access. See id.

12 Id. at 33. These locations include, among others, homes, friends' homes, schools, workplaces, libraries, community centers, and cyber cafés. See Brooke Bascom, Libraries Are Connecting Millions to the Internet, Digital. Divide NETwORK, at http://www.digitaldividenetwork.org/content/stories/-index.cfm?key=118 (last visited Dec. 30, 2001) (noting that libraries have emerged "as one of the most important vehicles for bridging the Digital Divide as they increase the availability of technology to patrons and elevate the technical expertise of staff"); see also Mark J. Maier, Affordable Internet Access for All Americans, 6 RicH. J.L. \& TeCH. 8, II 74-80 (1999), at http://www.richmond.edu/JOLT/-v6i2/article3.html (arguing that the government should provide Internet access in public libraries across the country).

13 Falling Through the Net IV, supra note 7 , at $\mathrm{xv.}$

14 See id. at 5 . The gap in Internet access between households in rural areas and households nationwide has narrowed from a 4.0 percentage point difference in 1998 to a 2.6 percentage point difference in 2000 . See $i d$. 
ternet usage between men and women has largely disappeared. ${ }^{15}$ Americans at the middle-income levels are connecting at far higher rates from their homes. ${ }^{16}$ And Internet access is expanding across every education level, particularly for those with some high school or college education. ${ }^{17}$ Blacks and Hispanics still lag behind other ethnic or racial groups; yet, they have shown impressive gains in Internet access. ${ }^{18}$ Although individuals older than fifty are still less likely than younger Americans to use the Internet, this age group has experienced the highest rates of growth in Internet usage compared to all other age groups. ${ }^{19}$ In sum, groups that have traditionally been the information have-nots have made dramatic gains in Internet access within the last few years.

Although the report showed that the digital divide in the United States is closing, ${ }^{20}$ the same is not true for the less developed countries. To date, the developed countries account for more than eighty percent of the world market for information technology, ${ }^{21}$ while Internet penetration is very limited in subSaharan Africa, the Middle East, Latin America, and South Asia. ${ }^{22}$ There are 510.5 computers per 1000 people in the United States, but only 3.2 per 1000 people in South Asia and 8.4 per 1000 people in sub-Saharan Africa ${ }^{23}$ Of the estimated 332 million people who use the Internet, less than 1 percent lives in Africa. ${ }^{24}$ In fact, some less developed countries do not even have basic telecommunications infrastructure or a reliable supply of electricity. ${ }^{25}$ Although

15 See id. at 33. In December 1998, $34.2 \%$ of men and $31.4 \%$ of women used the Internet. See id. By August 2000, "Internet use rates in the aggregate were virtually identical for men $(44.6 \%)$ and women $(44.2 \%)$." $I d$.

16 See id. at 8-9. Internet access among households with incomes between $\$ 35,000$ and $\$ 49,000$ rose from $29.0 \%$ in December 1998 to $46.1 \%$ in August 2000. See id.

17 See id. at 10-11. Of all education levels, households headed by someone with "some college experience" showed the greatest expansion in Internet penetration, rising from $30.2 \%$ in December 1998 to $49.0 \%$ in August 2000. See id.

18 See id. at 13. Between December 1998 and August 2000, Internet access for Black and Hispanic households doubled from $11.2 \%$ to $23.5 \%$ and from $12.6 \%$ to $23.6 \%$, respectively. See id.

19 See $i d$. at 33 . The $50+$ age group "saw faster growth in Internet use than the country as a whole, with Internet use growing at a rate of $53 \%$ compared to $36 \%$ for the country as a whole." Id. Individuals in this age group "were almost three times as likely to be Internet users if they were in the labor force." Id.

20 See id. at 2 (suggesting that the digital divide in the United States "has begun to narrow and will do so soon").

21 See NorRis, supra note 1 , at 41.

22 Id. at 233.

29 See World Bank, World Development Indicators 2001, at 308 (2001), available at http://www.worldbank.org/data/wdi2001/pdfs/tab5_10.pdf. 10 .

24 Marc Lacey, Clinton Hurries to Return to Camp David, N.Y. Tıмes, July 23, 2000, § 1, at

25 A similar lack of information infrastructure exists in many Indian communities in the United States. 
the developed world has about 50 phone lines per 100 people, the less developed countries have only 1.4 phone lines per 100 people.

In light of the alarming disparities between the information haves and have-nots, the Howard M. Squadron Program in Law, Media and Society at the Benjamin N. Cardozo School of Law, Yeshiva University selected the digital divide as the topic for its Second Squadron Symposium on Internet, Law \& Society. Included in this symposium issue are five articles and an issue brief.

Andrew Celli and Kenneth Dreifach point out that the digital divide is a multifaceted problem representing a "convergence of several fault lines." ${ }^{26}$ In addition to the access divide, which has captured both national and international attention, Celli and Dreifach discuss two additional divides. The capital divide reflects the inequalities in raising start-up money for business ventures on the Internet, ${ }^{27}$ while the treatment divide discriminates consumers based on their Internet browsing habits and purchasing preferences. ${ }^{28}$

Mark Cooper explains how the Internet and new communications technologies have created and widened the gap between the information haves and have-nots. ${ }^{29}$ Exploring the social implications of the digital divide, Cooper explains why this technological gap deserves all the public policy attention it has been receiving. ${ }^{30}$

Professor Allen Hammond explores the various aspects of the digital divide and discusses the balance between competition and safeguards struck by existing telecommunications law. ${ }^{31}$ Focusing on the current economic downturn in the high-tech industry, Professor Hammond cautions that this downturn "may serve as the occasion and motivation for defining the digital divide and reducing

Only 47 percent of the nation's 720,000 Indian households have plain old telephone service, compared with a nationwide rate of 94 percent, according to the F.C.C. And on some tribal lands, phone service is even rarer. On the Navajo Reservation, the nation's largest Indian territory, encompassing parts of New Mexico, Arizona and Utah, only about one in five households have telephones. Simon Romeo, Tribes Seeking Phone Systems as Steps to Web, N.Y. Times, Oct. 2, 2000, at A1; see also Marc Lacey, Clinton Hopes to Raise Indian Internet Use, N.Y. Times, Apr. 18, 2000, at A23 (reporting President's Clinton $\$ 17$-million initiative that offers $\$ 1$-a-month phone service to up to 300,000 Indians nationwide).

26 Andrew Celli \& Kenneth Dreifach, Postcards from the Edge: Surveying the Digital Divide, 20 Cardozo Arts \& ENT. L.J. 53, 54 (2002).

27 See id. at 62 (discussing the capital divide). Andrew Celli and Kenneth Dreifach argue that the capital divide "held back Internet opportunities conceived and/or oriented toward racial and ethnic minorities." Id. at 64-65.

28 See id. (discussing the treatment divide).

29 See Mark N. Cooper, Inequality in the Digital Society: Why the Digital Divide Deserves All the Attention It Gets, 20 Cardozo ARTs \& ENT. L.J. 73 (2002).

30 See id.

31 See Allen S. Hammond, The Digital Divide in the New Millennium, 20 Cardozo ArTs \& ENT. L.J. 135 (2002) [hereinafter Hammond, Digital Divide]. 
targeted subsidies." 32 He concludes by providing recommendations on how we could avoid this unfortunate outcome ${ }^{33}$

Jack Qiu shifts the focus from the United States to China. Qiu argues that the catchphrase "digital divide" is elusive in describing information inequalities in this vast and complex country. ${ }^{34}$ In lieu of this popular phrase, he proposes to use the concept of "information stratification," which, he argues, would better fit local Chinese conditions. ${ }^{35}$

At the end of the symposium is an issue brief by $B$. Keith Fulton, one of the most recognized authorities on digital divide issues in the United States. ${ }^{36}$ Detailing AOL Time Warner Foundation's portfolio of digital opportunity programs, this document provides insights into how the private sector plans and uses its resources to extend benefits of the information age. ${ }^{37}$

As an introduction to this symposium issue, this Article highlights the global significance of the digital divide. Part I discusses five key prerequisites for bridging this inequitable gap: awareness, access, affordability, availability, and adaptability. Part II focuses on the inequalities in Internet access between the developed and less developed countries. This Part explains why including the less developed countries in the digital revolution would benefit the developed countries as well as the less developed countries. Part III highlights the various areas that may present challenges for policies seeking to bridge the digital divide.

\section{Two D's AND FIVE A's ${ }^{38}$}

Although the origin of the term digital divide remains unknown, ${ }^{39}$ the term "has entered everyday speech as shorthand for

\footnotetext{
32 Id. at 140 .

33 See id. at 153.

34 See Jack Linchuan Qiu, Coming to Terms with Information Stratification in the People's Republic of China, 20 Cardozo ARTs \& ENT. L.J. 157 (2002).

35 Id. at 158.

36 See B. Keith Fulton, AOL Time Wamer Foundation: Extending Internet Benefits to All, 20 Cardozo Arts \& ENT. L.J. 181 (2002).

37 See id.

38 The "Two D's and Five A's" formula was inspired by the speech of Dr. Ahmad Nazif, Egypt's Minister of Communications and Information Technology, at a breakfast meeting held at the Center for Strategic and International Studies in Washington, D.C. At that occasion, Dr. Nazif noted the need to "transform the two Ds to three As," with the two Ds being the digital divide, and the three As being awareness, access, and affordability. See Mugo Macharia, The Global Digital Divide: An Egyptian Perspective, Digital Divide Network, at http://www.digitaldividenetwork.org/content/-stories/index.cfm?key=32 (last visited Dec. 30, 2001).

39 A Lexis-Nexis search traced the term back to Dinty W. Moore, The Emperor's Virtual Clothes: The Naked Truth About Internet Culture (1995). See Cyber-Santas Should Heed Computer-buying Tips from Staff and Wire Reports, Columbus Dispatch, Dec. 19,
} 
any and every disparity within the online community." 40 Covering a large range of communications technologies ${ }^{41}$ and "multiple layers" of access to and use of these technologies, ${ }^{42}$ the digital divide represents a multifaceted problem ${ }^{43}$ that encompasses a wide spectrum of disparities and differences based on race, gender, age, income, education, type of household, geographic location, physical abilities, and the level of economic development. As commentators cautioned, the term is so broad and ambiguous that it can be used by the left to support demands for universal service, broadband technologies, and philanthropy while at the same time by the

1995, at 8F. For an interesting discussion of the term's origin collected from Benton Foundation's Digital Divide Listserv, see http://www.rtpnet.org/lists/rtpnet-tact/ msg00080.html (last visited Dec. 30, 2001). Donna Hoffman and others attributed the term to Lloyd Morrisett, the former president of the Markle Foundation. See Donna L. Hoffman et al., The Evolution of the Digital Divide: How Gaps in Internet Access May Impact Electronic Commerce, J. Comp.-Mediated Comm. (March 2000), at http://www.ascusc.org/ $\mathrm{jcmc} / \mathrm{vol5} /$ issue3/hoffman.html. Yet, Morrisett expressed his skepticism about his coinage: "I am not at all certain that is true. My best guess is that someone else did it." Benjamin M. Compaine, Preface [hereinafter Compaine, Preface] to The Digital Drvide: Facing a Crisis or Creating a Mrth? xiv (Benjamin M. Compaine ed., 2001) [hereinafter Digital Divide Sourcebook].

40 Norris, supra note 1, at 3-4; Dean Colby, Conceptualizing the "Digital Divide:" Closing the “Gap" by Creating a Postmodern Network That Distributes the Productive Power of Speech, 6 Comm. L. \& POL'y 123, 123-24 (2001) (arguing that the digital divide "is the usefully alliterative slogan whose panpolitical ambiguity lends rhetorical capital to whomever [sic] chooses it").

41 These technologies include, among others, telephones, personal computers, the Internet, broadband services, mobile phones, satellite communications, and other wireless technologies.

42 Norris, supra note 1, at 92; see also Milton Mueller, Telecommunications Access in the Age of Electronic Commerce: Toward a Third-Generation Universal Service Policy, 49 FED. Comm. L.J. 655, 659 (1997); Qiu, supra note 34, at 162. As Pippa Norris pointed out:

[L] evels of Internet access can vary substantially. Today people living in poorer neighborhoods may be able to surf the Web from public libraries, schools, and community centers, or even cyber cafés, but this is not the same as having automatic access via high-speed connections at home and the office. Nor is it the same as having all Internet, all the time, downloadable via personal appliances, digital assistants, and cellular phones for today's wired road warriors in planes, ships, and trains.

Norris, supra note 1, at 92. A survey conducted by the Los Altos-based Access Worldwide Cultural Access Group found that both African Americans and Latinos "were less likely than the general population to seek financial or technological information online." Lee Romney, Minorities Use the Web Differently, L.A. Times, Jan. 16, 2001, at C2. While "African Americans were more likely than other groups to focus on career advancement and professional development, education, family and relationships and entertainment, . . Latinos . . . were more likely to use the Internet as a major source of news content, particularly for international news." $I d$.

43 See, e.g., Celli \& Dreifach, supra note 26, at 54 (noting that "the digital divide is not a single chasm, but the convergence of several fault lines"). Pippa Norris argued that the digital divide is "a multidimensional phenomenon encompassing three distinct aspects."

The global divide refers to the divergence of Internet access between industrialized and developing societies. The social divide concerns the gap between information rich and poor in each nation. And finally within the online community, the democratic divide signifies the difference between those who do, and do not, use the panoply of digital resources to engage, mobilize, and participate in public life.

NorRIS, supra note 1 , at 4 . 
right to promote further liberalization and commercialization of communications networks. ${ }^{44}$ To help people systematically analyze this technological gap, this Part discusses five key prerequisites for bridging the digital divide.

\section{A. Awareness}

It goes without saying that those who are not aware of the Internet and new communications technologies will not be able to benefit from the myriad opportunities created by the information revolution. Likewise, those who are not aware of the benefits of computers and online access will not be able to take advantage of the valuable digital opportunities. ${ }^{45}$ This lack of awareness is particularly acute among the poor, in rural areas, and in the less developed countries. Among the entire world population, only ten percent have access to the Internet, and an additional twenty percent have heard about the Internet. ${ }^{46}$ If the other seventy percent of the population were to be included in the digital economy, these people must become aware of the changing technological environment.

\section{B. Access}

Access to the Internet and new communications technologies is paramount to survival in the New Economy. Today, information technology increasingly determines the ease with which we conduct such daily activities as personal communication, business transactions, entertainment, education, job searches, research and information gathering, medical assistance, and political participation. ${ }^{47}$ They also enable us to "connect[] to family, friends,

44 See Colby, supra note 40, at 125-26; id. at 131 (criticizing the current digital divide policies for choosing the solution "in order to determine the possible problems"); see also Hammond, Digital Divide, supra note 31, at 135 ("Because each definer proffers a definition based on his or her perspective and may selectively emphasize particular statistical evidence, the definitions can seem conflicting and incongruous, potentially leading to confusion."); Testimony on Telecommunications and the Intermet:Hearing Before the House Comm. on Energy and Commerce, 108th Cong. 54 (2001) [hereinafter Chairman Powell's Testimony] (statement of Michael K. Powell, Chairman, Federal Communications Commission) (noting that the term is "extraordinarily broad and involves everything from notions of social justice to gaps in computer deployment to infrastructure to educational curriculum").

45 Among those American households that have never had an Internet connection, close to a third of them stated "don't want it" as the reason for not accessing the Internet at home. Falling Through the Net IV, supra note 7, at 26. Other leading reasons included "cost, too expensive" (17.3\%), "can use elsewhere" (10.4\%), "not enough time" (9.1\%), and "computer not capable" $(6.7 \%)$, Id.

46 Macharia, supra note 38.

47 See Allen S. Hammond, IV, The Telecommunications Act of 1996: Codifying the Digital Divide, 50 Fed. Coмm. L.]. 179, 182 (1997) [Hammond, Telecommunications Act] (noting that "[a]ccess to [telecommunications] networks increasingly determines the ease with 
schools, employers, political representatives, markets and society." 48 Without information technology, we will become the "New Invisible Man." 49 Our function as citizens, students, workers, and consumers in society also will diminish significantly. ${ }^{50}$

At the global level, computers and Internet access become even more important. As "the new basis for wealth," ${ }^{51}$ information technology will enable countries to acquire strengths that are lacking in countries that fail to participate in the digital economy. The information revolution also might allow the less developed countries to catch up with the developed countries by leapfrogging stages of technological, industrial, and infrastructural development. $^{52}$ To take advantage of these enormous benefits, the Clinton

which we can conduct and control financial affairs; pursue an education; acquire the skills to become employable; call for emergency police, fire, or medical assistance; apply for a job; work at a distance; or participate in the political process"); Maier, supra note 12, I 37 (noting that the Internet and new communications technologies "will permeate many aspects of life, including social interaction, cognitive skills, leisure activities, employment, and family life").

48 Hammond, Telecommunications Act, supra note 47, at 182; see also Jerry Kang, Cyber-race, 113 HaRv. L. REv. 1131, 1206 (2000) ("Cyberspace creates novel communication platforms that open up new possibilities in both individual identity and social interaction. By designing cyberspace appropriately, we may be able to alter American racial mechanics.").

49 Scott Louie, The New Invisible Man, Yo! Youth OutLook, available at http:// www.youthoutlook.org/stories/1999/11/01/the.new.invisib.html (Nov. 1, 1999) (describing the author's experience as "the new millennium's Invisible Man" after he unplugged his modem for a few days); see also Hammond, Telecommunications Act, supra note 47, at 185 ("As the networks and the equipment attached to them become the preferred mode of political participation, lifelong learning, employment and commerce, as well as personal expression, nonaccess and nonconnection could become tantamount to 'nonexistence.' ").

50 See Hammond, Telecommunications Act, supra note 47, at 184; see also id. at 185 (arguing that the information superhighway is the nation's "nervous system," the breakdown of which would jeopardize essential body parts and functions); Press Release, 3Com, 3Com CEO Eric Benhamou Provides Keynote Address on Digital Divide for Commonwealth Club of Silicon Valley, available at http://www.3com.com/corpinfo/en_US/pressbox/ press_release.jsp?INFO_ID=2001868 (July 19, 2000) ("[Information technology] access and [information technology] skills are no longer an option but an essential requirement for functioning in modern society and becoming a full participant in the new economy. We should think of it the same fundamental way as two centuries ago, when people thought of the skills of reading, writing, and counting."), quoted in William E. Kennard \& Elizabeth Evans Lyle, With Freedom Comes Responsibility: Ensuring That the Next Generation of Technologies Is Accessible, Usable and Affordable, 10 CommLaw Conspectus 5, 7 (2001).

51 Lester C. Thurow, Building Wealth: The New Rules for the Individuals, CompaNiES, and Nations in a KNOWLEDGe-BASEd Economy xiii (1999) ("Knowledge is the new basis for wealth .... In the past, when capitalists talked about their wealth, they were talking about their ownership of plant and equipment or natural resources. In the future when capitalists talk about their wealth, they will be talking about their control of knowledge."); see also James Boyle, Shamans, Software \& SpleEns: Law and the Construction OF INFORMATION SOCIETY 2 (1996) (stating that information "is a central feature of the international economy"); WIPO, THE MANAGEMENT OF INTERNET NAMES AND AdDREsSes: Intellectual Property Issues: Final Report of the WiPO Internet Domain Name ProCess I 12, at 4 (1999) [hereinafter Report of THE First WIPO InTernet Domain Name Process] (noting that "the source of wealth is increasingly intellectual, as opposed to physical, capital"), available at http://wipo2.wipo.int/process1/report/doc/report.doc.

52 See infra Part II.A (discussing the importance of bridging the global digital divide). 
Administration undertook aggressive efforts to bridge the digital divide by wiring classrooms, libraries, and rural health care providers in the United States. ${ }^{53}$

Although many people are aware of the potential and importance of the digital revolution, not all of them have access to communications technologies. Building a telecommunications infrastructure and creating technological applications require substantial investment of capital. Unfortunately, those communities that are in the most desperate need of basic information technology and telecommunications infrastructure rarely provide attractive markets. ${ }^{54}$ Nor do these communities possess the technological know-how needed to operate the new technologies. Even worse, many of these communities are struggling just to meet their basic needs, such as clean drinking water, food, shelter, electricity, schools, and basic health care. As a result, many people are forced to miss out on the opportunities created by the digital revolution.

Poverty and socio-economic constraints are not the only barriers to digital participation. Even in affluent societies, people with special needs, such as those with physical disabilities, may not be

53 One of the notable efforts in this area during the Clinton Administration was the ERate program, which required telecommunications carriers to provide discounted Internet hookups and connection for schools, libraries, and rural health care providers in the United States. See 47 U.S.C. $\$ 254$ (b) (6) (2000). Established pursuant to the universal service provisions under the Telecommunications Act of 1996, this program had accelerated the adoption of Internet technologies in American schools, libraries, and health care providers and had helped connect the younger generation to educational resources available on the Internet. See Kennard \& Lyle, supra note 50, at 6 (describing the achievements of the E-Rate Program); The E-rate in America: A Tale of Four Cities (Andy Carvin ed., 2000), available at http://www.benton.org/e-rate/e-rate.4cities.pdf (presenting four case studies of the E-Rate Program); see also Jessica L. Malman, Note, Connecting Students to "The Net': Guiding Principles from State Constitutions, 7 Geo. J. on Poverty L. \& Pol'y 53 (2000) (discussing the efforts to rectify the disparity between the level and quality of Internet access afforded to disadvantaged and more affluent students). For discussions of controversies surrounding the E-Rate Program and what many referred to as the "Gore Tax," see Angele A. Gilroy, Telecommunications Discounts for Schools and Libraries: The "E-Rate" Program and Controversies, CRS ISSUE BRIEF FOR CONGRESS, at http://www.cnie.org/nle/st-52.html (Sept. 15, 2000); Benton Foundation, Follow the E-Rate Debate, at http://uwww.benton.org/e-rate/ (last visited Dec. 30, 2001); Benjamin M. Compaine, The Advocates: Raising the Stakes, in Digital Divide Sourcebook, supra note 39, at 193 "With many teachers still at a loss on how to bring computers and the Internet into their classroom in a meaningful way, the multi-billion commitment of funds from the E-rate may be a leap of faith: Build it and hopefully they will come (before it gets obsolete).").

54 See Hammond, Telecommunications Act, supra note 47, at 188 (noting that "businesses seek out communities which have made the necessary investment in network infrastructure as part of their competitive strategy"); see also U.S. DEP'T OF COMMERCE \& U.S. DEP'T OF Agric., Advanced Telecommunications in Rural America: The Challenge of Bringing Broadrand Service to All Americans ii (2000) [hereinafter Advanced TelecommunicaTIONS in RuRal America] (noting that the primary reason for slower broadband deployment rate in rural America is economic), available at http://www.ntia.doc.gov/reports/ ruralbb42600.pdf. 
able to obtain access to information technology that many have taken for granted. Undeniably, the Internet has created a lot of unprecedented opportunities for people with disabilities and allow these people to complete tasks that they otherwise would not have been able to complete without others' assistance. ${ }^{55}$ However, because companies fail to consider their needs and physical limitations, many of them have to struggle on the unfortunate side of the digital divide. ${ }^{56}$ Fortunately, with the development of adaptive technologies, ${ }^{57}$ increasing government regulation, ${ }^{58}$ and widespread use of accessibility guidelines and policies for developing websites, ${ }^{59}$ many people with disabilities become able to cross the digital divide and to participate in the information revolution.

55 See Digital Divide Initiatives: Are They Accessible to People with Disabilities, DigrTal Divide NETwORK, at http://www.digitaldividenetwork.org/content/stories/index.cfm?key=76 (last visited Dec. 30, 2001) [hereinafter Digital Divide Initiatives] ("Paying bills, grocery shopping, and even learning about other adaptive technology and support services-tasks that previously forced people with disabilities to be dependent on others-can all be accomplished over the Internet with no assistance at all . ..."); Kennard \& Lyle, supra note 50, at 6-7 (describing how communications technologies have made the life of a deaf child much easier).

56 See Lawrence Lessig, Code and Other Laws of Cyberspace 66 (Basic Books 1999) [hereinafter LESsiG, CODE] ("When graphics entered the Net through the World Wide Web, the blind became 'blind' again."); Celli \& Dreifach, supra note 26, at 57 (describing the incompatibility of websites with software and equipment used by people with disabilities).

57 See Digital Divide Initiatives, supra note 55 ("Adaptive technology, such as text-tospeech output for blind and visually impaired and speech-to-text input for mobility impaired communities affords individuals unparalleled opportunities to independently accomplish numerous activities of daily life."); see also Deciphering Access for People with Disabilities, Digital. Divide. Network, at http://www.digitaldividenetwork.org/content/stories/index.cfm?key=188 (Oct. 1, 2001) (describing adaptive solutions that promotes Internet access for people with disabilities).

58 Section 508 of the Rehabilitation Act Amendments of 1998, 29 U.S.C. $\$ 794$ (d) (2000) (requiring federal agencies to accommodate the needs of the disabled when they develop, procure, maintain, or use electronic and information technology); see also Doe v. Mutual of Omaha Ins. Co., 179 F.3d 557, 559 (7th Cir. 1999) (finding in dicta that Title III of the American with Disabilities Act forbids owners and operators of a website to "exclude disabled persons from entering the facility and, once in, from using the facility in the same way that the nondisabled do"); Jonathan Bick, Americans with Disabilities Act and the Internet, 10 Alb. L.J. Sci. \& Tech. 205 (2000) (discussing section 508 of the Rehabilitation Act Amendments of 1998); Paul Taylor, The Americans with Disabilities Act and the Internet, 7 B.U. J. ScI. \& TECH. L. 26 (2001) (highlighting the costs of applying the ADA accessibility requirements to the Internet and the substantial First Amendment implications of applying such requirements to private Internet sites and services).

59 For example, many websites and information technology professionals have used the Web Content Accessibility Guidelines developed by the Web Accessibility Initiative of the World Wide Web Consortium (W3C). See Kennard \& Lyle, supra note 50, at 14 (describing W3C's accessibility guidelines); Digital Divide Initiatives, supra note 55 (describing the benefits of W3C's accessibility guidelines); see also Beth A. Haller, Ignored Aspect of Digital Divide, BALt. Sun, July 22, 2001, at 1C (explaining why bridging the digital divide makes good business sense); Jenny Strasburg, Pushing for Net Access, SAN Fran. EXAminer, Mar. 26, 2000, at B1 (articulating market-based arguments for making websites accessible to people with disabilities). 


\section{Affordability}

Not everybody can afford new communications technologies and the expenses incurred in upgrading the equipment, software, and training support. In most undeveloped or underdeveloped markets, the costs of hardware and software and the connection fees are so high that Internet access remains out of reach for most people in those markets. According to figures supplied by the United Nations, using the Internet for an hour in Chad in 1999 was $\$ 10.50$, while the average yearly salary of its inhabitants was only $\$ 187.60$ It would be hard to imagine why anyone would spend his or her entire annual income on using the Internet for less than twenty hours.

Worse still, with the increasing use of interactive graphics and multimedia technologies, such as Java applets, Shockwave animations, ActiveX controls, QuickTime audios, and RealAudio videos, high-speed Internet access may be needed to access information from sophisticated websites that gear toward high-end customers, many of whom already have installed broadband technologies. ${ }^{61}$ Unfortunately, most people in low-income neighborhoods, rural areas, and the less developed countries cannot afford these highspeed services. As Robert McChesney pointed out, in the United States alone, the expensive fees for high-speed Internet access "would all but rule out about half of [its] population." ${ }^{2}$ If half of Americans would be shut out of the broadband market, one might wonder how many of those in the less and least developed countries would be able to use these high-speed services.

So far, the high cost of Internet connection remains the major barrier to Internet access. However, as the New Economy becomes more developed and as companies put more protected information on the Internet, the cost of privatized Internet content may become a major factor of the unaffordability equation. ${ }^{63}$ Commentators repeatedly have documented the increased costs of privatized information. For example, "when data from the Landsat series of remote sensing satellites were privatized in the 1980s, the prices charged to most users, including academic and federal gov-

60 See U.N. Fears Divisive Impact of the Internet, N.Y. TIMEs, June 29, 2000, at A16.

61 See Michelle Kessler, Digital Divide Keeps Growing, USA Today, Nov. 2, 2001, at 4E ("The Digital divide used to be between Internet and non-Internet users. But as Websites become more elaborate, the gap grows between broadband and dial-up users.").

62 Robert W. McChesney, Rich Media, Poor Democracy: Communication Politics in Dubious Times 162 (1999).

63 See infra Part III.G (discussing the increased privatization of information and enclosure of the public domain). 
ernment users[,] increased from $\$ 400$ to $\$ 4,400$ per image." ${ }^{\prime 4}$ Likewise, after major corporate consolidations in the publishing field, average prices for scholarly and scientific research journals rose twenty to thirty percent. ${ }^{65}$ The journal Brain alone costs $\$ 15,000$ a year, ${ }^{66}$ beyond what most government agencies and university research libraries could afford.

\section{Availability}

Even with Internet access, many people may not be able to find information that is relevant to their lives and communities. ${ }^{67}$ Today, most Internet content is generated by companies that are driven primarily by their business interests. To maximize profits, these companies may tend to focus on the "right" customers, who have more disposable income and thus potential interests in their products. ${ }^{68}$ They also may carry content provided by themselves, their affiliates, and corporate partners, while clouting out information supplied by their competitors and other unaffiliated content providers. ${ }^{69}$ As a result, low-income and underserved Internet users may have difficulty in obtaining information that is relevant to their lives and communities. ${ }^{70}$ Without access to such content, these users would still be shut out of the digital revolution even if

64 J.H. Reichman \& Pamela Samuelson, Intellectual Property Rights in Data?, 50 VAND. L. REv. 51, 121 (1997).

65 See Ben H. Bagdikian, The Media Monopoly xli (6th ed. 2000).

66 See id.

67 See The Children's Partnership, Online Content for Low-income and Under Served Americans: The Digital Divide's New Frontier (2000) (noting the lack of materials and applications serving the needs and interests of low-income and underserved Internet users), available at http://www.childrenspartnership.org/pub/low_income/ low_income.pdf; Raneta Lawson Mack, The Digital Divide: Standing at the Intersec TION OF RACE \& TECHNOLOGY 167 (2001) ("No matter how reasonably priced personal computers are now or in the future, people will simply not embrace computer technology on a widespread basis until it is also shown to be relevant to their daily lives."); Kevin Taglang, Content and the Digital Divide: What Do People Want, Digital. Divide Network, at http://www.digitaldividenetwork.org/content/stories/-index.cfm?key=14 (Aug. 8, 2000) [hereinafter Taglang, Content and the Digital Divide] (noting that people need the ability to create or share community-relevant information to realize the full potential of the Internet).

68 See The Children's Partnership, supra note 67, at 17 (noting that "online content has been primarily designed for Internet users who have discretionary money to spend").

69 See Frank Rich, Two 21st Century Foxes Elope, N.Y. Times, Jan. 15, 2000, at A17 (noting that public interest groups "worry that AOL. Time Warner and its kin will run their fast Internet wires like private toll roads, banning other Internet providers or diverting them to slow and bumpy traffic lanes").

70 As Robert McChesney noted in his research on the commercial news media: In recent years, the increased focus by the commercial news media on the more affluent part of the population has reinforced and extended the class bias in the selection and tenor of material. Stories of great importance to tens of millions of Americans will fall through the cracks because those are not the "right" Americans, according to the standards of the corporate news media.

MCCHESNey, supra note 62, at xix. 
they have access to the Internet and new communications technologies.

Another barrier to digital participation is language. Due to the origin and early development of the Internet, ${ }^{71}$ most Internet content is available in English only. ${ }^{72}$ As a result, those who do not read English may have difficulty in locating information in a language they understand. ${ }^{73}$ Nonetheless, with the help of free online translation services and the increased production of Internet content in languages other than English, the language barrier on the Internet has been narrowing. In fact, forecasts cited at a recent United Nations-sponsored symposium on multilingual Internet addresses predict that Chinese will outrank English as the most widely-used language on the Internet by $2007 .{ }^{74}$

Furthermore, the lack of cultural diversity and local information makes the Internet unattractive to many people ${ }^{75}$ especially those in rural areas and in the less developed countries. In an insightful analogy, Professor Henry Louis Gates, Jr. compared the different attitudes between black and white families toward the

71 For interesting discussion of the origin of the Internet, see generally TiM BERNERsLee, Weavinc the Web: The Original Design and Ultimate Destiny of the World Wide Web (2000); Katie Hafner \& Matrhew Lyon, Where Wizards Stay Up Late: The Origins of the Internet (1998); John Naughton, A Brief History of the Future: From Radio Days to InTERnet YeArs in a Lifetime (2000).

72 See Hamish Mcrae, Only Deregulation and Competition Can Help Close the Digital Divide, INDEPENDENT (London), Jan. 19, 2001, at 20 (noting that "the Net is virtually a monolingual zone" for commercial applications).

73 As Pippa Norris noted:

A comprehensive analysis of more than one billion unique Web pages by the Inktomi search engine found that 87 percent of all documents were in English, a language understood by an estimated one in ten people worldwide. This picture is confirmed by a more limited search in 1997 by the Babel team for the Internet Society which estimated that 84 percent of all pages in English, followed by German (4.5 percent), Japanese (3.1 percent), French ( 1.8 percent), Spanish (1.2 percent), Swedish (1.1 percent), and Italian (1 percent), with all other languages each below 1 percent.

Norris, supra note 1, at 59-60; see also The Children's PARTNership, supra note 67, at 17 (noting that 87 percent of documents on the Internet are written in English and that at least 32 million Americans use a primary language other than English).

74 See Frances Williams, Chinese to Become Most-used Language on Web, FIn. Times, Dec. 7, 2001 , at 12 .

75 See The Children's Partnership, supra note 67, at 16 (describing the lack of local information on the Internet and that such a lack disproportionately affects Internet users living among low-income households); $i d$. at 17 (noting that the lack of cultural diversity in available Internet content serves as a barrier for many of the 26 million foreign-born Americans); Norris, supra note 1, at 60 (noting "the lack of Web content in indigenous languages, as well as the limited local relevance of the available sites, limits the incentive to go online for much of the population" in Southern Asia); Frederick Noronha, In a Software Superpower, Rural Kids Lack the Code to Learn, DigiTal Divide NeTwork, at http:// www.digitaldividenetwork.org/content/stories/-index.cfm?key=166 (last visited Dec. 30, 2001) (noting the lack of education software in Kannada language in India). 
Internet today to their different attitudes toward records in the 1920s:

Consider the birth of the recording industry in the 1920's. Blacks began to respond to this new medium only when mainstream companies like Columbia Records introduced so-called race records, blues and jazz discs aimed at a nascent AfricanAmerican market. Blacks who would never have dreamed of spending hard-earned funds for a record by Rudy Vallee or Kate Smith would stand in lines several blocks long to purchase the new Bessie Smith or Duke Ellington hit. ${ }^{76}$

If the Internet contained more diverse and relevant information, more people would be drawn to the Internet, and the gap between the information haves and have-nots might reduce. ${ }^{77}$ Interestingly, "despite the tremendous surge in ethnic portals, there is a lack of Internet content generated by ethnic communities themselves or organized around their unique cultural interests and practices."78

\section{E. Adaptability}

Access to information technology and Internet content is essential. However, such access is useful only if people are able to adapt to the changing technological environment and to use the new technological tools effectively. ${ }^{79}$ So far, computer illiteracy, technophobia, and cyberphobia have posed significant barriers to participation in the New Economy. ${ }^{80}$ Outdated structures and

76 Henry Louis Gates, Jr., One Internet, Two Nations, N.Y. Times, Oct. 31, 1999, \$ 4, at 15.

77 See Hoffman et al., supra note 39 (noting that an individual would be motivated to actively consume information if the information is of personal relevance to the individual or if it will be discussed in the individual's social circle).

78 Taglang, Content and the Digital Divide, supra note 67.

79 See id. ("To realize the potential of today's information tools, people need the skills to operate them to better their lives and the health of their communities."); Kennard \& Lyle, supra note 50, at 16-19 (emphasizing the need for the industry to ensure that the information technology is usable by all Americans who want to use it); William E. Kennard, Equality in the Information Age, 51 Fed. Comm. L.J. 553, 554 (1999) ("In the New Economy, every child without access to the Internet and without technology skills inherits a lifetime of missed opportunity."); Maier, supra note 12, II 37 ("Because of the pervasiveness of [information technology], a child who does not have adequate Internet access today, will be the handicapped citizen of tomorrow."); see also Okinawa Charter on Global InformaTION Society art. 11 (July 24, 2000) [hereinafter Okinawa CharTer] (emphasizing the need "to nurture [information and communication technology] literacy and skills through education, lifelong learning and training"), available at http://usinfo.state.gov/topical/ econ/group8/summit00/-wwwhinfo.html; Fulton, supra note 36, at 182 ("In a connected society, consumer demand, market prices, and disposable income are highly correlated with one's ability to read, write, do math and compute.").

80 See Amanda Lenhart, Who's Not Online: $57 \%$ of Those Without Internet Access Say They Do Not Plan to Loc on (2000) (finding that 54\% of those without Internet access considered the Internet dangerous), available at http://www.pewinternet.org/re- 
working practices also make it difficult for people to gain the full benefits of the digital economy. ${ }^{81}$

In low-income neighborhoods, rural areas, and the less developed countries, basic illiteracy creates an even more significant barrier to digital participation. ${ }^{82}$ Although the Internet is rich in visual imagery and audio content, most material on the Internet "remains closer to text-based newspapers rather than to audio or visual electronic media like television." ${ }^{3}$ Thus, basic illiteracy could still exclude a large segment of the world population from the information revolution "even if computing equipment became more widely available through Internet cafés, schools, public libraries, and community centers." ${ }^{44}$

\section{The Global Digital Divide}

\section{A. A Global Problem}

Information is the lifeblood of the New Economy. Today, the world is "approaching the point where not having access to [information technology] is likely to put an individual at a competitive disadvantage and in a position of being a less-than-full participant in the digital economy." 85 Information technology is no longer a luxury, but a development tool ${ }^{86}$ and a critical means of informa-

ports/pdfs/-Pew_Those_Not_Online_Report.pdf; MAck, supra note 67, at 3-33 (describing why minority communities might legitimately fear technological advancements and are therefore unlikely to immediately embrace computer technology); Beth Mazur, Barriers to Participation for Older Persons, DigiTal Divide NeTwORk, at http://www.digitaldividenetwork. org/content/stories/-index.cfm? key $=77$ (last visited Dec. 30, 2001) (listing computer illiteracy and cyberphobia as two major barriers for getting senior citizens online).

81 See Robert Taylor, Bridging the Digital Divide, Fin. Times, Feb, 22, 2001, at 11 (arguing that governments, companies, and employees must change their working practices to gain the full benefits of the New Economy).

82 See The Children's Partnership, supra note 67, at 17 (noting that the vast majority of Internet content is written for an audience that reads at an average or advanced literacy level, which is lacking in 22 percent of American adults); Digital Divide Network Staff, Benton Foundation, Digital Bridges Are Not Always Digital, Digital. Divide Network, at http://www.digitaldividenetwork.org/content/stories/index.cfm?key=40 (last visited Dec. 30 , 2001) (noting that basic illiteracy creates a major barrier to digital participation); see also Norris, supra note 1, at 59 ("One-fifth of the world's population remains illiterate, and the total rises to 40 percent or more of those living in Sub-Saharan Africa, the Middle East, and Southern Asia, with even higher figures for female population.").

83 NoRRIS, supra note 1 , at 59 .

84 Id.

85 Falling Through The NET IV, supra note 7, at 89; see also Norris, supra note 1, at 68 ("The chief concern about the digital divide is that the underclass of info-poor may become further marginalized in societies where basic computer skills are becoming essential for economic success and personal advancement, entry to good career and educational opportunities, full access to social networks, and opportunities for civic engagement.").

86 "In poorer villages and isolated communities, a well-placed computer, like a communal well or an irrigation pump, may become another development tool, providing essential information about storm warnings and crop price for farmers, or medical services and legal land records for villagers." NoRRIS, supra note 1, at 40-41; see also Celia W. Dugger, Connect- 
tion exchange in the New Economy.

As a recent report by the Department of Commerce noted, active participation in the information revolution will promote a country's economic development. ${ }^{87}$ Indeed, the Internet and new communications technologies offer the less developed countries unprecedented opportunities to acquire knowledge, "enhance educational systems, improve policy formation and execution, and widen the range of opportunities for business and the poor." 88 They also allow these countries to leapfrog conventional obstacles of technological, industrial, and infrastructural development. ${ }^{89}$

By realizing the full potential of the information revolution, countries could "meet[] more effectively their vital development goals, such as poverty reduction, health, sanitation, and education." 90 They also could foster market globalization, which, in turn, would increase the country's recognition in the international community, attracting foreign tourists and investors and allowing the country to benefit from global e-commerce. ${ }^{91}$ Moreover, through distance-learning technologies, students in the less developed countries would be able to "access the same electronic journals, books, and databases as students at the Sorbonne, Oxford, or Harvard." 92

Unfortunately, not all countries can benefit from the information revolution. Consider sub-Saharan Africa, for example. While the developed countries had hundreds of computers per 1000 people in 1999, there were only 8.4 per 1000 people in sub-Saharan Africa. ${ }^{93}$ "Half a billion people living [there] share 14 million phone lines, fewer than in Manhattan or in Tokyo." 94 And "for every 100 people there are only 17 radio sets, 5 televisions, and 0.5

ing Rural India to the World, N.Y. Times, May 28, 2000, at A10 (describing how a well-placed computer can link an isolated village in the southern tip of India to the borderless world of knowledge).

87 See Econ. \& Statistics Admin., U.S. Dep't of Commerce, Digital Economy 2000 vviii (2000), available at http://www.esa.doc.gov/De2000rev.pdf.

88 Norris, supra note 1, at 64 (quoting World Bank, World Development Report 9 (1999)).

89 See Okinawa Charter, supra note 79, art. 12.

$90 I d$.

91 See Norris, supra note 1, at 7 (noting that the Internet allows "small craft industries and the tourism industry in Bali or the Maldives [to] deal directly with customers and vacationers in New York, and London, irrespective of distance, the costs of advertising, and the intermediate distribution chains of travel agents and retail businesses"); Thomas L. Friedman, Digital Divide or Dividend, N.Y. TIMEs, Mar. 16, 2001, at A19 (describing how the Internet could reward sustainable cultural practices and create a global market for indigenous cultures).

92 Norris, supra note 1, at 7; see also Mike Bowler, Library Bridges a Digital Divide, BALT. Sun, Feb. 21, 2001, at 2B (describing the potential of digital libraries).

93 WORLd BANK, supra note 23, at 308.

94 NorRIs, supra note 1 , at 16. 
percent mobile phones." 95 "Even at ... universities, where technology usage is most pronounced, most institutions are plagued by the absence of phones, electrical outlets, and an inadequate national infrastructure." ${ }^{96}$

When viewed in terms of the quality of the services provided, the picture becomes even gloomier. For example, the phone systems "are spotty and often rely on antiquated equipment, and [their] progress is hamstrung by bureaucracy, outdated administrative structures and, in most instances, state-owned monopolies." 97 Likewise, the power distribution network is grossly inadequate, irregular, and sometimes nonexistent, and power supply remains unavailable in many rural areas. ${ }^{98}$ To make matters even worse, countries in the region are constantly troubled by a large variety of domestic problems, such as "ineffective government and weak institutions; poverty; ethnicity; power struggles within and among the elite; poor services and weak public institutions; corruption and nepotism; faulty allocation of resources; foreign interference; and instability as a result of that very fluid and political culture." 99

Nonetheless, the situation is improving with large-scale sharing of information resources, ${ }^{100}$ increasing liberalization of the telecommuni-cations sector and the Internet market, and active de-

95 Id.

96 J.M. Spectar, Bridging the Global Digital Divide: Frameworks for Access and the World Wireless Web, 26 N.C. J. INT'L L. \& CoM. ReG. 57, 63 (2000). As one commentator noted:

A survey by the Association of African Universities found that while 52 of the 232 academic and research institutions had full Internet connectivity, 180 others had "inadequate" access. While most institutions have some e-mail services, "many are unable to provide meaningful Internet access." In addition, most African universities are "facing severe financial crises," thus making it "impossible for many institutions to tap into the technological revolution."

Id. (internal citations omitted).

97 Daniel Akst \& Mike Jensen, Africa Goes Online, Digital Divide Network, at http:// www.digitaldividenetwork.org/content/stories/index.cfm?key=158 (June 2, 2001).

98 See id. "In many countries the power distribution network does not reach significantly into rural areas, and 'power sharing' (regularly scheduled outages lasting for many hours) is a regular occurrence, even in some capital cities." Id.

99 Africa Ready to Undo Past Errors and Confront Truth, No Matter How Painful, Security Council Told; Council Hears 37 Speakers in Day-long Meeting on Africa, M2 Presswire, Jan. 30, 2002, available at Lexis, News Library, ALLNWS File (quoting Zambia's Minister of Foreign Affairs).

100 One commentator suggested that the large-scale sharing of information resources in Africa might pave the way for widespread use of shared public Internet terminals:

[L] arge-scale sharing of information resources is a dominant feature of the African media landscape. A given copy of any newspaper might be read by more than ten people, there are usually perhaps three users per dial-up Internet account, and it is not uncommon to find most of a small village crowded around the only TV set, often powered by a car battery or small generator. Why not shared public Internet terminals?

Akst \& Jensen, supra note 97. 
ployment of information technology. ${ }^{101}$ For example, Kenya "recently established the first public Internet peering point exchange for [Internet service providers] in Africa outside of South Africa." ${ }^{102}$ It also "rolled out its first national Internet backbone connecting six cities with the use of digital switches, fiber-optic cable and satellite services." 103 Likewise, Nigeria opened up its Internet market by licensing thirty-eight Internet service providers to sell services. ${ }^{104}$

Moreover, countries in Africa have worked together to build a regional Internet backbone. Among the best known and most important telecommunications projects is Africa One, which "aims to put a 32,000 kilometer optical fiber necklace around the entire continent by 2002." ${ }^{05}$ According to the company, the project, once complete, "will not only vastly expand telephone and Internet capacity on the continent, but will also eliminate $\$ 600$ million a year in connection fees that Africans pay to complete international telephone calls-many of them between African nations." 106

Some commentators have questioned the urgency of efforts to bridge the global digital divide and contended that the divide is only a temporary phenomenon that will fade gradually over time. ${ }^{107}$ As they explained, the cost of information technology is

101 “AfricaOnline [alone] had approximately 100000 users spread across 740 outlets in Cote d'Ivoire, Kenya, Uganda, Tanzania and Zimbabwe before it began its new programme of fewer, llarge [sic] branded I-cafes." The African Internet-A Status Report, DicitaL DIvidE NeTwork, at http://www.digitaldividenetwork.org/content/stories/index.cfm?key=147 (last visited Dec. 30, 2001). For the latest update on Internet development in Africa, see $i d$. 102 Akst \& Jensen, supra note 97. "A peering point is a neutral computer where [Internet service providers] can exchange traffic between their respective users without having to do so via their international links. That saves time and bandwidth." Id.

103 Id.

104 See id. Twelve of these providers have since become active. See id.

105 Id. For an overview of Africa One, see Wiring a Continent for the 21st Century: The Africa

ONE Project Overview, at http://www.africaone.com/english/about/about.cfm.

106 Akst \& Jensen, supra note 97.

107 See, e.g., Henry H. Perritt, Jr., Economic and Other Barriers to Electronic Commerce, $21 \mathrm{U}$. PA. J. INT'L ECON. L. 563, 565 (2000) (arguing that concerns about the digital divide are "overblown" because Internet technology continues to lower the cost of bringing electronic commerce to a poor person or one located in a rural area with poor infrastructure); Lloyd Morrisett, Foreword to Digital Divide Sourcebook, supra note 39, at ix (asserting the author's belief that "controversies about the 'digital divide' will fade away"); Robert $W$. Crandall, The Digital Divide: Bridging the Digital Divide-Nalurally, Brookincs Rev., Jan. 1, 2001, at 38 (arguing that "[g]overnment policymakers should relax and let the booming economy close the digital divide"); Adam D. Thierer, How Free Computers Are Filling the Digital Divide, Heritage Found. Backgrounder, Apr. 20, 2000 (arguing that there is no digital divide crisis as the costs of Internet connectivity are decreasing and as Internet penetration occurs more rapidly than previous technologies had), available at http:// www.heritage.org/library/-backgrounder/pdf/bg_1361.pdf; Eric Cohen, United We Surf, Whly. STANDARD, Feb. 28, 2000, at 26 (noting that the digital divide "is based more on myth than reality, and offers only mythical solutions to real problems"); Adam Clayton Powell, III, Falling for the Gap: Whatever Happened to the Digital Divide?, in DigrTal Divide SOURCEBOOK, supra note 39, at 309 ("Misled by stereotypes, misinformed about survey tech- 
decreasing rapidly, while the quality of Internet service is improving quickly. Thus, new communications technologies may create a window of opportunities that allows the less developed countries to catch up with the developed countries, ${ }^{108}$ just like how Internet start-ups caught up with the bricks-and-mortar companies. ${ }^{109}$ Indeed, a recent report by the Organization for Economic Cooperation and Development (OECD) noted that "expenditure in nonOECD countries has been growing at more than double the OECD average, with especially rapid expansion in telecommunications and [information technology] hardware investments in Brazil and China." 110

Other commentators are less optimistic, however. As they pointed out, information revolution benefits not only the less developed countries, but also the developed countries. ${ }^{111}$ Although a fast follower may sometimes perform better than a first mover in some commercial situations, "in terms of power among states, it is usually better to be a first mover than a fast follower."112 After all, first movers in the information technology field "are often the creators of the standards and architecture of information systems." 13

nologies, and misdirected by interest groups, the media have treated the digital divide as a crisis requiring government intervention."), available at http://reason.com/9911/ fe.ap.falling.shtml; Jube Shiver, Jr., Big Bandage for a Narrowing Internet Gap, L.A. Tımes, Jan. 29,2000 , at A1 (noting that "government intervention [to bridge the digital divide] is not needed and is a waste of money in an age of low cost computers and online access"). But see Hammond, Digital Divide, supra note 31, at 136 (criticizing this argument for its failure "to acknowledge the near-term dangers of exclusion when time is measured in Internet, rather than standard, years").

108 World Bank Economist Carlos Braga expressed his optimism:

Although, no doubt, income and wealth inequality may increase in the initial stages of the process, catch-up can also happen at a much faster pace than in the past. [Information and communication technology] spending, for example, grew more quickly in most developing regions than in high-income economies in the 1992-97 period. And countries like South Africa and Brazil already boast a higher share of networked personal computers than most industrialized economies.

Carlos Alberto Primo Braga, Inclusion or Exclusion, Le Courier, Dec. 1998, available at http://www.unesco.org/courier/1998_12/uk/dossier/txt21.htm; see also RoBERT O. KeOHANE \& JOSEPH S. NYE, POWER AND INTERDEPENDENCE 221 (3d ed. 2001) (noting that information technology may minimize costs, create economies of scale, lower market entry barriers, and reduce the power of the large states while enhancing the power of small states and nonstate actors).

109 "In less than a decade, innovative companies with the flexibility and imagination to take advantage of digital technologies, such as Amazon.com and eBay, have challenged the market share held by established companies." NorrIs, supra note 1, at 239. Although thousands of these start-ups failed in the recent dot-com crash, some succeeded and continues to grow despite the crash.

$110 \mathrm{Id}$. at 41 .

111 See KeOHANE \& NYE, supra note 108, at 221 (arguing that some aspects of the information revolution help the small states while others help the already large and powerful).

$112 I d$. at 222.

$113 I d$. 
In fact, given the lack of technological know-how and communications infrastructure, the information revolution might make it more difficult for the less developed countries to catch up. Thus, one might wonder whether new communications technologies would widen the economic disparity between the developed and less developed countries. ${ }^{114}$

To date, " $[\mathrm{t}]$ he World Bank, the United Nations, and the G-8 have expressed alarm that poorer societies lacking technological investment will drift farther behind their wired rivals in the global marketplace, whereas advanced industrialized societies will surge even farther ahead on the back of dramatic productivity gains."115 To narrow this widening technological gap, "[m]ultiple policy initiatives have been proposed, such as investment in technological infrastructure in Malaysia, computer training and education in schools in Latvia, and innovative community-level schemes in Bangladesh."116

A good example is the Digital Opportunity Taskforce (Dot Force) established by the leading industrialized countries at the recent G-8 summit in Okinawa. On that occasion, the leading industrialized countries called for "both the public and private sectors to bridge the international information and knowledge divide." 117 As they declared in the Okinawa Charter on Global Information Society:

Our vision of an information society is one that better enables people to fulfil their potential and realise their aspirations. To this end we must ensure that [information and communication technology] serves the mutually supportive goals of creating sustainable economic growth, enhancing the public welfare, and

114 As Pippa Norris described:

If investment in digital technologies has the capacity to boost productivity, advanced economies such as Sweden, Australia, and the United States at the forefront of the technological revolution may be well placed to pull even farther ahead, maintaining their edge in future decades. A few middle-level economies like Taiwan, Brazil, and South Korea may manage to leverage themselves profitably into niche markets within the global marketplace, servicing international corporations based elsewhere by providing software development or manufacturing silicon chips. But most poorer societies, lagging far behind, plagued by multiple burdens of debt, disease, and ignorance, may join the digital world decades later and, in the long-term, may ultimately fail to catch up.

Norris, supra note 1, at 5; see also Francisco Rodríguez \& Ernest J. Wilson, III, Are Poor Countries Losinc the Information Revolution? (The World Bank InfoDev Working Paper Series 2000) (noting the growing disparity in information and communication technologies between rich and poor countries), available at http://www.infodev.org/library/ wilsonrodriguez.doc.

115 NorRIs, supra note 1 , at 39.

$116 I d$.

117 Okinawa Charter, supra note 79, art. 5. 
fostering social cohesion, and work to fully realise its potential to strengthen democracy, increase transparency and accountability in governance, promote human rights, enhance cultural diversity, and to foster international peace and stability. ${ }^{118}$

Pursuant to this Charter, the G-8 established the dot force to assist in integrating the less developed countries in the emerging global information network; to facilitate a dialogue and cooperation between the developed and less developed countries, international organizations, and the private sector; and to increase the global awareness of challenges and opportunities caused by the digital revolution. ${ }^{19}$

\section{B. Global Benefits}

Although commentators and policymakers sometimes describe efforts to bridge the digital divide as a "moral imperative" and as a matter of social justice, ${ }^{120}$ there are many nonaltruistic reasons why the developed countries should help bridge the global digital divide.

First, like all other communications technologies-such as telephone, television, cable, and fax machines-the Internet exhibits powerful network effects. ${ }^{121}$ The more computers are connected and the more information technology is deployed, the

\footnotetext{
$118 I d$. art. 2.
}

119 See id. art. 18.

120 See Spectar, supra note 96, at 86-87 (quoting Arnold Ph. Djiwatampu, Social Justice Through Communications Access: A Little LEO Proposal, ITU News, May 2000 Spec. Ed., at 40, 42, available at http://www.itu.int/journal/200004/E/pdf/n0400e.pdf).

121 See Dan L. Burk, The Trouble with Trespass, 4 J. Small \& Emerging Bus. L. 27, $50-52$ (2000) (noting the network externalities created by the Internet); Mark A. Lemley \& David McGowan, Legal Implications of Network Economic Effects, 86 CAL. L. REv. 479, 545-62 (1998) (discussing the network effects exhibited by the telephone industry and the Internet); George Gilder, Metcalfe's Law and Legacy, Forbes, Sept. 13, 1993, at 158 (describing Metcalfe's Law, which demonstrates that a network's value grows in proportion to the number of users and information sources connected to it). See generally Dennis W. Carlton \& J. Mark Klamer, The Need for Coordination Among Firms, with Special Reference to Network Industries, 50 U. CHI. L. Rev. 446 (1983) (discussing the need for coordinated action among firms in the network industries to achieve efficiency).

Professors Mark Lemley and David McGowan pointed out that the Internet warrants special analysis as it includes aspects of many types of networks.

[C] ommunication on the Internet requires adherence to common technical protocols that, in an elemental sense, define the scope of the Internet. Internet users are not actually linked to one another, however. Rather, the protocols that define the "boundaries" of the Internet merely facilitate software interoperability. Further, not everyone on the Internet wants to be connected to everyone else; some would prefer that access to the Internet remain limited, or at least that they be able to shut themselves off from the masses in a private group. Nonetheless, at least a significant part of the value of the Internet itself is the fact that it enables communication among users; in this sense, it is a classic actual network with characteristics similar to the telephone.

Lemley \& McGowan, supra note 121, at 494 (footnote omitted). 
greater is the value of the Internet connection. An increase in Internet penetration in the less developed countries therefore would increase the benefits of Internet users and service providers in the developed world. Further improvement in the information infrastructure of the less developed countries also would accelerate the speed of the Internet. After all, the practical speed of any network is limited by the slowest link on that network regardless of the network's maximum capacity. ${ }^{122}$ Moreover, as Mark Cooper pointed out in his article in this symposium issue, due to the different rush hours created by the varying time zones, spreading the user base across geographic areas would allow the Internet to maximize its capacity and to balance its access load. ${ }^{123}$

Second, information about foreign countries-developed or otherwise-is badly needed in this increasingly globalized world. Today, people no longer can live exclusively within their territorial borders without any knowledge of the rest of the world. ${ }^{124}$ Bridging the global digital divide therefore would facilitate the flow of information from the less developed countries to the developed countries, and vice versa. Such an effort would enable citizens and businesses in the developed countries to make more informed decisions about matters concerning foreign countries and the global community. It also would allow those in the less developed countries to acquire information about the global trading system, thus enabling them to understand better how to compete successfully in, and to integrate into, the international economy.

Third, the free exchange of information can help countries acquire what Dean Joseph Nye and Professor Robert Keohane called "soft power." As these two distinguished political scientists defined:

Soft power . . . is the ability to get desired outcomes because others want what you want; it is the ability to achieve desired outcomes through attraction rather than coercion. It works by convincing others to follow or getting them to agree to norms and institutions that produce the desired behavior. Soft power can rest on the appeal of one's ideas or culture or the ability to set the agenda through standards and institutions that shape the preferences of others. It depends largely on the persuasiveness of the free information that an actor seeks to transmit. If a state

122 See Peter H. Lewis, Picking the Right Data Superhighway, N.Y. TImEs, Nov. 11, 1999, at $\mathrm{G} 1$.

123 See Cooper, supra note 29 , at 85.

124 See Maier, supra note 12, I11 ("No longer can Americans live exclusively within our continental borders without any knowledge of the rest of the world."). 
can make its power legitimate in the eyes of others and establish international institutions that encourage others to define their interests in compatible ways, it may not need to expend as many of its costly traditional economic or military resources. ${ }^{125}$

The soft power of the developed countries, including the United States, can be derived from the appeal of ideas such as democracy, the rule of law, human rights, and individual freedom. Bridging the global digital divide therefore would help spread the cultures of these countries and therefore would increase the awareness of their ideas among the less developed world. ${ }^{126}$ Such awareness is particularly important in closed societies run by authoritarian governments, in which alternative sources of information are woefully deficient. ${ }^{127}$

Fourth, due to the "rudderless, decentralized, and transnational" nature of the Internet architecture, regulation of the Internet is inherently difficult. ${ }^{128}$ Indeed, in many countries in Asia, the Middle East, Europe, and Latin America, greater freedom is found on the Internet than in the traditional news media. ${ }^{129}$ Bridging the global digital divide therefore would facilitate the flow of information that helps subvert authoritarian and repressive governments, ${ }^{130}$ thus promoting democracy, ${ }^{131}$ human rights, ${ }^{132}$

\footnotetext{
125 KeOhane \& Nye, supra note 108, at 220.

126 See id. at 221.

127 Robert Keohane and Joseph Nye offered an illuminating example:

One of the Iranian students who organized the takeover of the United States embassy and seizure of hostages in 1979 recently said, "For Americans freedom is an everyday commodity, but for us, under the Shah's dictatorship, it was something unknown. So when we took the embassy, we acted on the basis of what we knew, and that was despotism. Today we have chosen a different course, based on what we learned from the last twenty years.
} Id. at 253.

128 Neil Weinstock Netanel, Cyberspace 2.0, 79 TEx. L. REv. 447, 448 (2000); see also NorRIS, supra note 1, at 100 (noting that "officials normally find it far more difficult to silence critical voices on the new media compared with their ability to regulate and control the TV airwaves"); A. Michael Froomkin, The Internet as a Source of Regulatory Arbitrage, in Borders in Cyberspace: Information Policy and the Global Information Infrastructure 129 (Brian Kahin \& Charles Nesson ed., 1997) (discussing the difficulties of censorship on the Internet); David R. Johnson \& David G. Post, Law and Borders-The Rise of Law in Cyberspace, 48 STAN. L. REv. 1367, 1373-74 (1996) (describing how efforts to control the flow of electronic information across physical borders will likely fail).

129 See Leonard R. Sussman, The Internet in Flux, in Freedom House, How Free?: The Web \& The Press: The Annual Survey of Press Freedom 4 (2001) [hereinafter 2001 FreeDOM House SuRvey], available at http://www.freedomhouse.org/pfs2001/pfs2001.pdf.

130 As Mark Maier noted:

From the economic crisis in Russia to the conflict in Kosovo, the Internet is providing the means of communication to people who would otherwise be silenced by repressive governments. Communication via the Internet survives even after dictatorial govern-ments destroy traditional means of communication, such as broadcast radio. For example, Radio B92, the Kosovo radio station that was shut down by the Serbian government, has continued to broadcast via the Internet. Also, after the Serbian government deported all western journal- 
and civil society, ${ }^{133}$ as well as transparency, openness, and accountability of governing agencies. ${ }^{134}$

In countries where the mass media are tightly controlled, heavily censored, and cost-prohibitive, the Internet and new communications technologies would create opportunities for electronic expression by individuals and groups who otherwise would not have media access. ${ }^{135}$ A good example is the Kosovo radio sta-

ists, current news reports were still accessible via the Internet from various individuals, and even a monastery.

Maier, supra note 12, I 11 (footnotes omitted); see also Hiawatha Bray, The Wiring of a Continent / the World, Boston GLOBE, July 22, 2001, at A1 (noting that "political activists in Nigeria, Ghana, and other countries are using the Internet to rally international opposition to corrupt or oppressive rulers").

Interestingly, the online community is more interested in political change than the existing community in physical space. As commentators noted, the online community is "more tolerant of alternative lifestyles, more sympathetic toward new social movements, more secular toward moral values, more liberal in general on the social issues although also more pro-business on the economic agenda." NorRIS, supra note 1 , at 238 . If these characteristics held true for the less developed countries, promoting Internet development in those countries would help "accelerate the process of value change associated with [political and] societal modernization." Id.

131 See generally Christopher R. Kedzie, Communication and Democracy: Coincident Revolutions and the Emergent Dictator's Dilemma (1997) (demonstrating a strong correlation between democratization and interconnectivity), available at http:// www.rand.org/publications/RGSD/RGSD127. See also Paul M. Schwartz, Privacy and Democracy in Cyberspace, 52 VAND. L. REv. 1607, 1610 (1999) (noting that "cyberspace has a tremendous potential to revitalize democratic self-governance at a time when a declining level of participation in communal life endangers civil society in the United States"); Mark Malloch Brown, Democracy and the Information Revolution, CHorces, Sept. 2001 (describing how the information revolution is "an equally powerful revolution for democracy and democratic governance"), available at http://www.undp.org/dpa/choices/2001/september/ commentary.pdf; Gary W. Selnow, The Internet and the Soul of Democracy, Digital Divide NETwORK, at http://www.digitaldividenetwork.org/-content/stories/index.cfm?key=191 (Oct. 9, 2001) (arguing that the Internet, due to its interactive nature, has the ability to "cultivate the soul of democracy"). But see NorRIs, supra note 1, at 22 (arguing that digital politics in the developed world "functions mainly to engage the engaged"); Dana Ott, Power to the People: The Role of Electronic Media in Promoting Democracy in Africa, FIRST MoNDAY, at http://www.firstmonday.dk/issues/issue3_4/ott (Apr. 6, 1998) (arguing that electronic information will not promote democracy in the absence of parallel efforts ensuring that access to the Internet is not restricted to urban, elite populations) For a symposium on Internet voting and its impact on American democracy, see Symposium, Internet Voting and Democracy, 34 Loy. L.A. L. Rev. 979 (2001).

132 See generally Peter Brophy \& Edward Halpin, Through the Net to Freedom: Information, the Internet and Human Rights, 25 J. INFo. SCI. 351 (1999).

133 As one commentator explained:

New communication technologies enable citizens of prospective democracies to learn more about how other societies operate. If they discover that others living elsewhere live more freely and appear to have a higher quality of life, not only in a materialistic sense, they are inclined to seek more freedom and democracy for themselves.

KEDzIE, supra note 131, $\$ 5$, at http://www.rand.org/publications/RGSD/RGSD127/ sec5.html.

134 See Norris, supra note 1, at 104 (noting "the ability of the Internet to provide information promoting the transparency, openness, and accountability of governing agencies at national and international levels").

135 See Hammond, Telecommunications Act, supra note 47, at 200 (noting that the Internet and new communications technologies "have occasioned greater opportunities for elec- 
tion Radio B92, which continued to broadcast via the Internet after the Serbian government had shut down the station. ${ }^{136}$ With shrinking costs, maximizing speed, and broadening reach, information technology also would alter the balance between established organizations and outside challengers. ${ }^{137}$ In addition, by promoting independent and investigative journalism, ${ }^{138}$ it would allow the media to function as the Fourth Estate, ${ }^{139}$ providing diversity and a multiplicity of viewpoints and facilitating informed deliberation by citizens.

Compared with the traditional news media, the Internet and new communications technologies would "provide[ ] a more level playing field for party competition," 140 thus increasing the leverage of small and emerging parties. ${ }^{141}$ Undeniably, major parties have greater resources to create and maintain professionally-designed websites that utilize the newest, fastest, and most attractive technologies. ${ }^{142}$ However, information technology enables smaller and

tronic expression by individuals and groups who use, but do not own, media”); see also Howard Rheingold, Electronic Democracy: The Great Equalizer, Whole EARTH Rev., June 22, 1991, at 4 (arguing that telecommunications "can equalize the balance of power between citizens and power brokers"). But see Norris, supra note 1, at 101 (cautioning that the Internet in authoritarian regimes "may serve as a traditional agency of state propaganda, strengthening the government's grip, rather than providing a channel for opposition parties and groups").

136 See Maier, supra note 12, If 11; see also Arab States Slow in Opening Up to the Internet, Deutsche Presse-Agentur, Oct. 21, 2001, available al Lexis, News Library, ALLNWS File ("In Tunisia, journalists have been publishing online magazines ever since their application to publish printed products was ignored by the authorities." (internal quotations omitted)).

137 See Norkis, supra note 1, at 20 ("The explosive growth of connectivity via the Internet alters the transmission of information among networks, shrinking costs, maximizing speed, broadening reach, and eradicating distance. Potentially these changes can have profound consequences for altering the balance of resources and power between outsider challengers and established organizations within the political system.").

138 See id. at 100 ("Independent journalism benefits from the relatively low start-up and production costs for an online weekly newsletter or daily newspaper, compared with production and distribution costs of the printed press, or the capital investments required for radio or TV stations."); Maier, supra note 12, I 11 (noting that the Internet encourages people and their governments to base their opinions and conduct on current information from independent sources).

139 See Maier, supra note 12, I 12 ("Governments will find it harder to bamboozle their citizens with misleading information, since those same people will be able to access independent information from the Internet."). See generally LuCAS A. POWE, JR., THE FOURTH Estate and THE Constitution (1991) for a discussion of how the press serves as an autonomous, independent check on government.

140 Norris, supra note 1 , at 156.

141 This is particularly important in countries that are making transition from communism to democracy, because the communist party in those countries usually remains the largest and most dominant party in those countries.

142 See id. (noting that "major parties will probably have greater financial and personnel resources to create and maintain professionally designed websites complete with the latest multimedia bells and whistles like Java script and Macromedia, steaming audiovisuals, and opportunities for processing electronic commerce such as secure online payment of membership dues or campaign donations"). 
fringe parties to catch up with major ones. By using free shareware and web-hosting facilities, "[a] few enthusiastic party supporters with know-how and technical skills can create a professional-looking site." ${ }^{43}$ Domain names, search engines, and portals-such as Yahoo!, AOL, and Google-also would allow the general public to find sites by these parties with greater ease. ${ }^{144}$

Finally, although information technology can create an appeal for the ideas and ways of life in the developed world, it also presents a vivid picture of the backwardness of the less developed countries and of the enormous disparities between the developed and less developed world. ${ }^{145}$ To some commentators, these disparities are far from coincidence and are largely attributed to the unfair international economic system, which, these commentators argue, benefits the developed countries at the expense of the less developed countries. Attempts to bridge the global digital divide not only would alleviate mistrust among the less developed countries, but also would help reduce the tension in the world trading system and the sense of isolation among people living in those countries. ${ }^{146}$ They also would promote global harmony by strengthening the voice of those countries and by countering the role of international intergovernmental organizations. ${ }^{147}$

Indeed, if dissatisfaction among the less developed countries continues to grow and if the global digital divide persists, global stability and international security might be at stake. Eventually, the global digital divide might separate the world into two camps, causing the less developed countries to demand a "new international order" that provides equitable access to information technology, redistributes information resources under global norms, and brings fundamental changes to the global economic system. ${ }^{148}$

143 Id. at 154-56; see also id. at 170 (noting the "modest differences among major, minor and fringe electoral parties").

144 See id. at 156 (noting that "the barriers to being listed [in search engines] are minimal compared with the difficulties of gaining sustained coverage in the mainstream news media").

145 See David Kirkpatrick, Tech into Plowshares, Fortune, Oct. 15, 2001, at 211.

146 See Norris, supra note 1 , at 66.

147 See $i d$. at 8 (describing the potential of information technology to "foster[ ] a worldwide civic society countering the role of international agencies, strengthening the voice of the developing world, dissolving some of the boundaries of the nation-state, and reinforcing the process of democratization").

148 Such an order would be similar to UNESCO's New World Information and Communications Order (NWICO). NWICO was an extension of the New International Economic Order, which attempted to bring about fundamental changes in the international economic system by redistributing power, wealth, and resources from the developed North to the less developed South. See Spectar, supra note 96, at 57 (contending "new order"-style restructuring schemes would be ineffective in and counterproductive to bridging the global digital divide). 
Commentators have sometimes justified this order by equating knowledge with common heritage ${ }^{149}$ and access to information technology with a fundamental human right. ${ }^{150}$ Although this order may be effective in protecting the less developed countries, it might bring the world back to the 1970 s and 1980 s, when negotiation for international telecommunications was deadlocked. ${ }^{151}$

Even worse, some radicals might turn to extremism, violence, and terrorism to voice their dissatisfaction with the existing system. Since the September 11 terrorist attacks in New York and Washington, commentators, including myself, have noted the ties between the attacks and the global inequalities in Internet access. ${ }^{152}$ These ties might have more profound implications when one recalls Karl Polanyi's classical work, The Great Transformation. ${ }^{153}$ In this book, Polanyi demonstrated how the social disruptions and inequalities caused by the Industrial Revolution and globalization in the nineteenth century had led to the political reactions of fascism and communism. ${ }^{154}$ If history were to repeat itself, the tension created by the digital revolution and the globalization in the New Economy was particularly alarming.

\footnotetext{
149 See, e.g., Ronald Wellington Brown, Economic and Trade Related Aspects of Transborder Data Flow: Elements of a Code for Transnational Commerce, 6 J. INT'L L. \& Bus. 1, 66 n.228 (noting that the parties to the Declaration of Buenos Aires on Transborder Data Flow agreed "to encourage all international actions and policies on harmonization leading to consider informatics as Mankind's Heritage"); Carl Q. Christol, The Common Heritage of Mankind Provision in the 1979 Agreement Governing the Activities of States on the Moon and Other Celestial Bodies, 14 INT'L L.AW. 429, 451 (1980) (considering scientific information gleaned from the moon, broadcast spectra, and orbital positions as part of "intangible natural resources" of the moon that can be designated as the common heritage of mankind); Vigdis Finnbogadottir, Closing Speech at the Second International Congress on Ethical, Legal and Societal Challenges of Cyberspace (Oct. 3, 1998) (advocating the creation of freeware that "give[s] the public ... new access to the great heritage of all people on Earth, and all the knowledge that could serve to improve the world"), available at http://www.unesco. org/webworld/infoethics_2/eng/-closing_remarks.htm.

150 See Finnbogadóttir, supra note 149 (advocating "a new vision of innovations and access to them, based on the premise that information technology is by its very nature a human right, ought to be regarded as an obvious human right, and ranks alongside the concept of human liberty itself").

151 See Spectar, supra note 96 , at 68-80 (describing the troubled negotiations on international telecommunications during the 1970 s and 1980s); see also id. at 57 (noting that "North-South debates concerning access to information and equitable allocation of spectrum have often mired the international telecommunications negotiations of the last two decades").

152 See, e.g., David Wardrop, A Place for Peace in the IT Revolution, Digital Divide NetwORK, at http://www.digitaldividenetwork.org/content/stories/index.cfm?key=199 (Nov. 5, 2001); Peter K. Yu, Terrorism and the Global Digital Divide: Why Bridging the Divide Is Even More Important After September 11, FindLaw's WRi'T: Lecal Commentary, at http:// writ.news.findlaw.com/commentary/-20020211_yu.html (Feb. 11, 2002).

153 Karl Polanyi, The Great Transformation (Octagon Books 1975).

154 See id.
} 


\section{Challenges Ahead}

\section{A. An Ever-changing Definition}

Ever since the debate on the digital divide began, the definition of this divide has changed many times. This change is largely attributed to the rapid development of the Internet, the proliferation of digital tools and new communications technologies, and the constant evolution of the information society. After all, "Internet technology is not going to stand still as long as the market continues to demand ever smaller, faster, and improved forms of delivery." 155

"In 1980, a gigabyte of storage cost several hundred thousand dollars and occupied a room. It now fits on a credit-card device that can be carried in your pocket." ${ }^{156}$ Just a few years ago, a 56 kbps dial-up telephone modem was the state-of-the-art technology for personal communications. Today, Internet users demand fat pipes, fast connection and transmission speeds, and more advanced forms of information delivery, such as cable, DSL, ISDN, or even wireless technologies-all of which were, until recently, limited to businesses and the privileged few who could afford to pay hundreds or thousands of dollars per month for high-speed Internet access. ${ }^{157}$

In light of this technological change, the definition of the digital divide (and thus the basic tools needed to survive in the digital economy) will change over time. ${ }^{158}$ Although it is very difficult to

155 NorRIs, supra note 1 , at 92.

156 Id. at 8.

157 As Peter Lewis wrote:

The key to happiness in the Internet age is bandwidth. Bandwidth, bandwidth, bandwidth. Fat pipes, capable of sucking down Web pages, music files, video clips, e-mail and other forms of digital information and entertainment from the Internet in the blink of an eye. A data spigot that is always open, without busy signals and without the kinds of delays and service interruptions that drive most computer users mad.

Lewis, supra note 122 , at G1.

158 Not all of the new communications technologies and services should be included in the definition of the digital divide. Mark Maier put forward this argument by analogizing Internet services to postal services:

Although the Internet is an important utility that offers many services, not all of these services need to be made available to all Americans. This is analogous to the U.S. Postal Service that provides basic service to all Americans at an inexpensive price. For additional or special services such as express delivery, there are added costs and competition from private firms such as Federal Express or UPS. For example, one can send a first class letter anywhere in the United States for the affordable price of only thirty-three cents. However, if overnight service is required from Massachusetts to California, there are a number of providers that offer this service at prices of ten to twenty dollars.

Internet access should be provided in a similar manner. Basic Internet service could include browsing the Internet and sending electronic mail (e- 
determine what should constitute these basic tools, ${ }^{159}$ we should constantly review and update the definition so that it corresponds to the rapidly changing technological environment. ${ }^{160}$ As former Federal Communications Commission ("FCC") Chairman William Kennard noted, "[t]he landscape of communications is changing dramatically. Being connected will not just be about having phone and perhaps Internet service. It will mean broadband delivery of increasingly converging services such as interactive voice, data and full motion video." ${ }^{161}$ The modem divide might have dominated the digital divide debate in the past couple of years; the broadband divide, however, could be the main focus of the debate in the years to come.

When the Department of Commerce started tracking the digital divide in 1994, it merely measured the level of telephone, computer, and computer-household modem penetration. ${ }^{162}$ The Internet, which had yet to become popular, was only mentioned twice-once in the background section and once as a footnote. ${ }^{163}$ By the time the third report was issued in 1999, the word "Internet"

mail). Advanced services such as application hosting should not be included in a basic Internet access service package; rather, they should be available at free market prices.

Maier, supra note 12 , II 18-19.

159 As former FCC Chairman William Kennard pointed out:

Of course at this stage of deployment of advanced services, it is too early to predict what services will be considered so critical that they must be universally affordable. Some technologies, which seem so promising when they are first introduced, will never be accepted by a critical mass of consumers, as was the case with the betamax home video technology. Other technologies, like the television, will achieve almost $100 \%$ penetration without any special intervention. Still other technologies, such as compact disc players, will not be deemed critical enough to ensure that they are universally affordable.

Kennard \& Lyle, supra note 50, at 19. Indeed, as Andrew Shapiro pointed out, predicting how technology will evolve is "notoriously difficult":

Thomas Edison, after all, originally conceived of his phonograph as a way to record one's thoughts and send them to friends. And the telephone was used early on in a few places to pipe music into homes from distant concert halls. Trying to assess the long-term social and political impact of a technology is even trickier. Certainly no one predicted that the television would become a kind of baby-sitter. The rapid pace of Net's growth makes it even more difficult to assess is impact.

Andrew L. Shapiro, The Control, Revolution: How Internet Is Putting Individuals in Charge and Ghanging the World We Know 18 (1999).

160 To reflect this rapidly changing technological environment, Professor Allen Hammond included in his proposal an explicit disclaimer that his proposal "does not account for further changes or upgrades in existing technology, nor does it address what new issues of equity might arise should a revolutionary technology or application present itself and destabilize the broadband market." Hammond, Digital Divide, supra note 31, at 155.

161 Kennard \& Lyle, supra note 50, at 5; see also Manuel Castells, The Internet galaxy: Reflections on THE INTERNET, Business AND SOCIETY 256 (2001) (noting that "[a]s soon as one source of technological inequality seems to be diminishing, another one emerges").

162 See Falling Through the Net I, supra note 7.

163 See id. The word "Web" was mentioned in the same endnote. See id. n.2. 
was everywhere. ${ }^{164}$ The survey went even further in its final report, which was released in 2000 , by including a separate section on high-speed Internet access. ${ }^{165}$ As the report noted, "[ $\left.t\right]$ here are large differences in high-speed access based on income and other variables, and these initial data will enable [the administration] to track the increases and diffusion of high-speed access as broadband infrastructure is widely adopted."166

Just as we anticipate the arrival of new communications technologies, we need to anticipate new ways of living brought about by the digital revolution. For example, the increased mobility of the economy and the extensive use of mobile phones and other wireless technologies have enabled people to move with ease from one place to another and to become "wired road warriors" who spend a substantial amount of time away from home or traditional workplace. ${ }^{167}$ As a result, the underlying assumptions of some of the existing telecommunications policies may become invalid. As Professor Milton Mueller pointed out insightfully:

Telecommunications access is no longer one simple, homogeneous thing. It is becoming increasingly specialized and heterogeneous. Those who predicted that electronic communications would all "converge" into a single, broadband, integrated network are plainly wrong. Access is diverging into many different forms. Most people will consume more than one of these access technologies. They may have a fixed voice service at home, but they will also have some kind of data communication account, and/or a pager account, a telephone credit or debit card, an ATM card, and some kind of entertainment-oriented video account or subscription. Users will want to be able to move in and out of different types of networks depending on which one is most appropriate to their needs at a given time. ${ }^{168}$

In light of these changing ways of living, a definition that focuses solely on computer usage at home or at work might be

164 For the first time, this report addressed Internet penetration among American households and individuals. See Falling Through THE Net III, supra note 7, at 33-75. The report cited two reasons for including an in-depth examination of Internet access and usage. "First, given the Internet's 'robust growth,' the Internet has assumed an importance in Americans' everyday lives that compels us to probe more deeply into this new medium. Second, a sufficient number of people are now online, enabling meaningful surveying and statistically significant analyses." Id. at 33.

165 See Falling Through the Net IV, supra note 7, at 23-25; see also id. at xiii (noting that the survey examined for the first time household access to high-speed Internet services).

166 Id. at xiii.

167 NoRRIS, supra note 1 , at 92.

168 Mueller, supra note 42, at 659. 
misguided. ${ }^{169}$

Finally, different communities have different conditions and thus require different solutions. A definition that is useful in one community may be irrelevant in another. As a result, we should be sensitive to the particular conditions of a community and constantly evaluate whether the definition makes sense in light of those conditions. For example, in places where basic information infrastructure is underdeveloped, next-generation communications technologies, such as wireless broadband technologies, may provide better solutions than to upgrade the state of technologies currently in place. ${ }^{170}$ Indeed, many commentators considered broadband wireless technologies a viable solution to the networking needs of the Indian Country, many parts of which lacks even basic telecommunications services. ${ }^{171}$ Thus, if we insisted on defining the digital divide without paying attention to the needs and constraints of the affected communities and the existence and potential of new communications technologies, we might misperceive and mischaracterize the problem, further aggravating the plight of the information have-nots.

\section{B. An Endless Race}

One could hardly finish a race if the referee kept extending the finish line. With the ever-changing definitions of the digital divide, one might wonder whether the digital divide will ever be bridged. Although it is important that we have a finish line, it is more important that we are running quickly toward the finish line. The key goal of a digital divide policy is not to eradicate absolute equalities of access to all information via all networks at all time, but to ensure that each person has meaningful access to the Internet and new communications technologies and that each person can fully participate in the digital revolution.

As Pippa Norris noted, absolute social inequalities will con-

\footnotetext{
169 See id. at 660-61 (noting the increasing mobility of the economy and that "most people spend a large portion of their waking hours outside of the home").

170 See Celli \& Dreifach, supra note 26, at 60 (noting that "[s]atellite and wireless technologies require far less terrestrial infrastructure than broadband technology, and thus might offer a more economical means for speeding up rural connection"); Kade L. Twist, Native Networking Trends: Wireless Broadband Networks, Digital Divide Nerwork, at http:// www.digitaldividenetwork.org/-content/stories/index.cfm?key=186 (Sept. 24, 2001) [hereinafter Twist, Native Networking Trends] (noting that technologically leapfrogging" requires the "deploy[ment of] next-generation communication technologies rather than trying to improve the state of technologies currently in place"); see also ADVANCED TELECOMMUNICATIONS IN RuRAl AmERicA, supra note 54, at ii (noting that "[s] atellite broadband service has particular potential for rural areas as the geographic location of the customer has virtually no effect on the cost of providing service").

171 See, e.g., Twist, Native Networking Trends, supra note 170.
} 
tinue to exist in Internet access just as they exist in other dimensions of life. ${ }^{172}$ Given the substantial inequalities in access to telephone and cable services, ${ }^{173}$ "it would be naive to expect that the Internet will magically transcend information poverty overnight," ${ }^{74}$ Thus, we should focus on the relative inequalities and ensure that the Internet and new communications technologies do not make people's lives more difficult than inequalities of access currently existed in other forms of communications technologies, such as telephones and televisions. ${ }^{175}$

The same logic applies to the global inequalities in Internet access. Today, there are "substantial disparities in every ... dimensions of life from health care and nutrition to education and longevity." ${ }^{176}$ It therefore would be naive to expect that there will be no absolute inequalities between rich and poor nations in the virtual world. ${ }^{177}$ It also would be unrealistic to assume that the Internet would "suddenly eradicate the fundamental and intractable problems of disease, debt, and disadvantage facing developing countries." 178 After all, many of the poor living in Namibia, Brazil, and Bangladesh do not even have newspapers, radios, and television, let alone networked computers and an information superhighway. ${ }^{179}$

\section{The Mercedes Divide}

When the Bush Administration appointed Michael Powell as the Chairman of the FCC, the new appointee was eager to distance himself from the activist approaches of his Clinton-appointed predecessors, Reed Hundt and William Kennard. ${ }^{180}$ Emphasizing a

172 See Norris, supra note 1, at 12; see also Compaine, Preface, supra note 39, at xii (noting that "there have been and will continue to be many gaps-between those who knew how to farm and those who did not in the Agriculture Age; those who could fix an engine and those who could not in the Industrial Age; and those who could use a computing appliance and those who could not in the Information Age").

173 As Pippa Norris pointed out:

Although Alexander Graham Bell's commercial telephone service was launched in the United States in 1877, today in America, more than a century later, there remain pockets of racial inequality in access to household telephones. Cable TV started to become available in the mid-1960s but today, owing to choice or necessity, only two-thirds of American households are connected, along with about half of all households in industrialized nations.

NorRis, supra note 1 , at 12.

174 Id.

175 See id. at 49.

$176 I d$

177 See id.

$178 I d$

179 See id. at 66.

180 See Jeffrey Chester \& Gary O. Larson, Whose First Amendment?: Media Conglomeration as Free Speech, Am. Prospect, Dec. 17, 2001, at 28. 
hands-off approach, Chairman Powell considered the digital divide "a dangerous phrase ... [that] could be used to justify government entitlement programs that guaranteed poor people cheaper access to new technology, like digital television sets or computers." ${ }^{181}$ In a comment he later regretted, ${ }^{182}$ he compared the digital divide to a "Mercedes divide": "I think there is a Mercedes divide. I would like to have one, but I can't afford one."183

Likewise, Bill Gates is not convinced of the urgency of efforts to bridge the global digital divide. According to him, what the very poor countries need is clean drinking water, food, schools, and medicine, rather than computers. ${ }^{184}$ In a digital divide conference in Seattle in 2000, Gates questioned if people knew what it meant to live on $\$ 1$ a day: "There's no electricity in that house. None. . . You're just buying food, you're trying to stay alive." ${ }^{185}$ He further elaborated his remarks in a follow-up interview:

The mothers are going to walk right up to that computer and

181 Stephen Labaton, New F.C.C. Chief Would Curb Agency Reach, N.Y. Times, Feb. 7, 2001, at $\mathrm{Cl}$.

182 In a subsequent congressional hearing, Chairman Powell expressed regret for his comment on the Mercedes Divide. See Chairman Pouell's Testimony, supra note 44 (stating that the Mercedes comment was "regrettable"); see also Celli \& Dreifach, supra note 26, at $61 \mathrm{n.52}$ (discussing the congressional hearing and Chairman Powell's regret about his Mercedes comment).

183 Christopher Stern, New FCC Chairman Favors a Non-Activist Approach, WaSH. Post, Feb. 7, 2001, at E1. For a critical response to Chairman Powell's remarks by Larry Irving, the former Assistant Secretary of Commerce for Communications and Information and Administrator of the National Telecommunications and Information Administration, see Larry Irving, Michael Powell's 'Mercedes Divide,' WASH. PosT, June 30, 2001, at A30. See also Celli \& Dreifach, supra note 26, at 61 (criticizing Powell's comment on the Mercedes divide); Labaton, supra note 181, at C1 (reporting that consumer groups considered Powell's comment insensitive, elitist, and "unnecessarily inflammatory"); Rita Ciolli, Getting Across the Great Digital Divide, NewSDAY, Feb. 21, 2001, at C2 (reporting criticisms of the Chairman Powell's comment).

As many commentators have pointed out, Chairman's Powell remarks were somewhat unfair. Many people would be happy just to have a Toyota, a Chevy, or even a $\$ 500$ used car. According to former FCC Chairman William Kennard, "The analogy is not between having a Mercedes or a Toyota. It's between having a car or not having a car." Peter G. Gosselin, Private Prosperities, Public Breakdowns, L.A. TImes, Aug. 5, 2001, at A1; see also Clarence Page, FCC's Powell Must Help Close 'Digital Divide,' NewsDaY, Feb. 12, 2001, at A22 (quoting one consumer advocate as saying "A Mercedes? A lot of people will settle for a bus!"). In the information age, computers and Internet access are no longer luxuries, but essential communication tools in the New Economy.

184 See Sam Howe Verhovek, Bill Gates Turns Skeptical on Digital Solution's Scope, N.Y. Tımes, Nov. 3, 2000, at A18 (reporting that Bill Gates discussed in a digital divide conference about how computers and information technology would not be able to solve immediate problems of the world's poorest people); World's Widest Divide Is Hardly Digital, SeATtLe Times, Oct. 21, 2000, at A15 (noting that Bill Gates continues to argue that the divides between water, food, schools, and health are more important than the digital divide).

185 Verhovek, supra note 184, at A18; see also Bill Gates, Remarks at the Creating Digital Dividends Conference in Seattle, Washington (Oct. 18, 2000), available at http:// www.microsoft.com/billgates/speeches/2000/10-18digitaldividends.asp. 
say, "My children are dying, what can you do?" They're not going to sit there and like, browse eBay or something. What they want is for their children to live. They don't want their children's growth to be stunted. Do you really have to put in computers to figure that out? ${ }^{186}$

Although these remarks were disappointing to those who have devoted a lot of time, energy, and resources to bridge the digital divide, these remarks reminded us of the sad reality and cautioned us not to mistake the tree for the forest. There are a lot of different divides, and the digital divide is only one of them. Thus, no matter how important the digital divide is, it should not overshadow those traditional issues that continue to divide the rich and the poor.

Nonetheless, just as we should not dismiss the racial divide by noting the existence of the education divide, we should not dismiss the digital divide by noting the existence of other divides. The digital revolution has changed virtually every aspect of our lives. The failure to take advantage of digital opportunities therefore will disenfranchise an important segment of our population.

Moreover, solutions to the digital divide and other, more traditional divides can work together to reinforce each other. For example, there is an intertwining relationship between economic development and the growth of information technology. The previous Part has already demonstrated how information revolution can lead to greater economic development. ${ }^{187}$ The converse also could be true. "If countries have the income and affluence then often (but not always) access to the Internet will follow, along with connectivity to telephones, radios, and televisions." 188 Thus, "improving health, food, education and net access should not be seen as being in opposition to each other. They are all part of the solution." 189

\section{A Changing Legal Order}

Commentators have emphasized ad nauseum how the Internet and new communications technologies have transformed the global economy and the international political system. However,

186 Verhovek, supra note 184 , at A18.

187 See supra Part II.A.

188 Norris, supra note 1, at 67; see also id. at 233 (arguing that the root cause of global inequalities in digital access is the lack of economic development). "There are some important exceptions to this generalization-both affluent countries that lack extensive Internet access such as Kuwait and Greece, and middle-income countries that have made great progress toward online connectivity, such as Slovakia and Estonia." Id. at 67.

189 Victor Keegan, Online: Divide and Rule Out, Guardian, Dec. 14, 2000, at 2. 
"information does not flow in a vacuum, but in political space that is already occupied." 190 As Professor Lawrence Lessig pointed out repeatedly, code is law and the Internet is regulable. ${ }^{191}$ As a result, legal regimes, norms, and rules eventually will determine what sorts of communities would thrive in cyberspace, how information will diffuse from one country to another, and ultimately how much and how fully a country can participate in the New Economy.

A good example is the development of the Internet domain name system. Traditionally, Internet domain names are registered on a first-come, first-served basis. Under this system, domain names that are vital to the development of some communities may be taken by squatters who have no connections with these communities, yet who are interested to obtain economic benefits through predatory practices. Although the World Intellectual Property Organization ("WIPO") was reluctant to recommend changes to the existing registration systems during the Second WIPO Internet Domain Name Process, ${ }^{192}$ it acknowledged the existence of arguments that "the first-come, first-served nature of domain name registration systems exploit the digital divide and disadvantage authorities in countries with less developed infrastructures for the Internet in establishing their own identity in the [domain name system]."193

Moreover, whenever there are rules, there are always questions of authority. Because cyberspace is regulable, " $[c]$ lassic issues of politics-who governs, on what terms? who benefits?-are as relevant to cyberspace as to traditionally physical space."194 Thus, whether the global digital divide will be eventually bridged will depend on how the international community resolves these political

190 KeOhane \& NyE, supra note 108, at 217.

191 See Lessic, Code, supra note 56. For articles advocating the self-governance of cyberspace, see, for example, Johnson \& Post, supra note 128; David G. Post, Anarchy, State, and the Internet: An Essay on Law-Making in Cyberspace, $1995 \mathrm{~J}$. ONLine L., at http:// www.wm.edu/law/publications/jol/-articles/post.shtml; I. Trotter Hardy, The Proper Legal Regime for "Cyberspace," 55 U. PITT. L. Rev. 993 (1994); Henry H. Perritt, Jr., Cyberspace Selfgovernment: Town Hall Democracy or Rediscovered Royalism?, 12 BERKELEY TECH. L.J. 413 (1997); Edward J. Valauskas, Lex Networkia: Understanding the Internet Community, FIRST MONDAY, at http://www.firstmonday.dk/issues/issue4/valauskas/index.html (Oct. 7, 1996). But see Jack L. Goldsmith, Against Cyberanarchy, 65 U. CHI. L. REv. 1199 (1998) (disputing the need to distinguish between cyberspace and real-space transactions and advocating the need to ground cyberspace transactions in real-space laws).

192 See WIPO, The Recognition of Rights and the Use of Names in the Internet Domain Name System: Report of the Second WIPO Internet Domain Name Process (2001) [hereinafter Final Report of SEcond WIPO Domain Name Process], available at http://wipo2.wipo.int/process2/report/pdf/report.pdf. For a summary of the Report, see Peter K. Yu, A Summary of the Final Report of the Second WIPO Internet Domain Name Process, GIGAL_Aw.COM, at http:/ / www.gigalaw.com/articles/2002/yu-2002-01.html (Jan. 2002).

193 Final Report of Second WIPO Domain Name Process, supra note 192, II 246, at 107.

194 KeOHANe \& NyE, supra note 108, at 216. 
issues and whether the stronger, developed countries would impose rules on the weaker, less developed countries. An egalitarian platform and a predictable, transparent, and non-discriminatory regulatory environment therefore is necessary for the development of a global information society. When devising the regulatory environment, members of the international community should pay special attention to the needs and constraints of the less developed countries, the socially under-privileged, people with disabilities, and senior citizens.

\section{E. Censor Dot Gov ${ }^{195}$}

Government censorship has long been the major barrier to Internet access. A recent survey by Freedom House indicated that more than nineteen countries thoroughly restrict their citizens' access to the Internet. ${ }^{196}$ Cited examples include cyberdissidents jailed in China, ${ }^{197}$ state-controlled Internet service providers and firewalls put up by governments in Saudi Arabia, ${ }^{198}$ and the requirement by the Russian president that Internet service providers channel messages through security forces for potential monitoring. ${ }^{199}$ By enforcing a strict information control policy, these countries successfully protect the power of the ruling elites and prevent citizens from obtaining access to subversive ideas from the outside world.

Consider the Taliban regime in Afghanistan. Long before the September 11 terrorist attacks in New York and Washington, the Taliban government had banned television and the Internet. ${ }^{200}$ As

195 This subtitle was borrowed from Leonard R. Sussman, Censor Dot Gov: The Internet and Press Freedom 2000 [hereinafter Sussman, Censor Dot Gov], in Freedom House, Press FREEDOM SURVEY 2000 (2000), available at http://www.freedomhouse.org/pfs2000/ pfsmap2k.pdf.

196 See Country Ratings: Press Freedom Worldwide [hereinafter Country Ratings], in 2001 Freedom House Survey, supra note 129, at 11, 41; see also Sussman, Censor Dot Gov, supra note 195 (exploring whether the Internet will become a censor's web worldwide). Data are unavailable for 29.5 percent of the 187 countries surveyed. See Sussman, The Internet in Flux, supra note 129, at 1 . For example, Afghanistan, which banned the Internet, was not rated in the survey. See Country Ratings, supra, at 196.

197 See Sussman, The Internet in Flux, supra note 129, at 2; see also ShanThi Kalathil \& Taylor C. Boas, The Internet and State Control in Authoritarian Regimes: China, Cuba, and the Counterrevolution (Carnegie Endowment for International Peace Information Revolution and World Politics Project Working Papers 2001) (demonstrating how China and Cuba are maintaining control over the Internet's political impact through different combinations of reactive and proactive strategies), available at http://www.ceip.org/ files/pdf/21KalathilBoas.pdf; Peter K. Yu, Barriers to Foreign Investment in the Chinese Internet Industry, GicALAw.COM, at http://www.gigalaw.com/articles/2001/yu-2001-03.html (Mar. 2001) (discussing the regulation of the Internet industry in China).

198 See Sussman, The Internet in Flux, supra note 129, at 3.

199 See id. at 4.

200 See Arab States Slow in Opening Up to the Internet, supra note 136. For an insightful 
the Taliban foreign minister explained, "[w]e are not against the Internet, but it is being used to disseminate obscenities, immorality, and propaganda against Islam." ${ }^{201}$ As a result of the Taliban policy, the Afghans were not only devoid of information technology and digital opportunities, but were shut out of information that can help the country progress. Ironically, notwithstanding its ban on the Internet, the Taliban understood the importance of digital communication and "maintain[ed] a website promoting recognition of its regime worldwide."202

Today, overt censorship by the government has become more and more rare. In lieu of overt censorship, governments may take on policies that induce self-censorship by the business community. Indeed, many corporations practice self-censorship to protect their business interests. For example, in an effort not to offend the Chinese government, Rupert Murdoch eliminated the BBC from his satellite service, Star Television, after the Chinese government protested the news service's coverage of Chinese political dissidents. ${ }^{203}$ HarperCollins, a publishing house owned by Murdoch, also cancelled its contract to publish the memoirs of Christopher Patten, the last governor of Hong Kong. ${ }^{204}$

Likewise, although Disney insisted on its release of Kundun ${ }^{205}$ - a film biography of the Dalai Lama-despite the Chinese government's protests and subsequent "freezing" of its media projects, ${ }^{206}$ Disney dissociated itself from the film by eliminating virtually any reference to the media conglomerate in its advertising. ${ }^{207}$ To smooth things over with the Chinese government, Disney also took numerous conciliatory efforts, including the hiring of super-lobbyist Henry Kissinger, the appointment of special personnel to coordinate its Chinese activities, a visit to Beijing by its CEO

discussion of the emergence of Taliban regime of Afghanistan, see generally AHMED Rashid, Taliban: Militant Islam, Oil and Fundamentalism in Central Asia (2000).

201 Arab States Slow in Opening Up to the Internet, supra note 136 (quoting Wakil Ahed Mutawakil, foreign minister of the Taliban regime of Afghanistan).

202 Country Ratings, supra note 196, at 11.

203 See Richard W. Stevenson, Mondo Murdoch: Networking, Globally and Relentlessly, N.Y. Times, May 29, 1994, $\$ 4$, at 1 .

204 See Warren Hoge, Murdoch Halts a Book Critical of China, N.Y. Times, Feb. 28, 1998, at A5. This incident was notably ignored in Murdoch's newspapers and news media. See MCChesney, supra note 62, at 116; Murdoch Hunt, Fin. Times, Mar. 2, 1998, at 21. Governor Patten's book, which was subsequently published by Macmillan, was expected to be highly critical of China. See Christopher Patten, East and West: The Last Governor of Hong Kong on Power, Freedom and the Future (1999).

205 Kundun (Buena Vista Pictures 1997).

206 See Joyce Barnathan et al., Has Disney Become the Forbidden Studio?, Bus. Wк., Aug. 4, 1997, at 51; Robert W. Welkos \& Maggie Farley, Insulted by Films, Beijing Orders Halt to Studio Deals, L.A. Times, Oct. 31, 1997, at A1.

207 See MCCHESNEY, supra note 62, at 115. 
Michael Eisner, and the promise to build a theme park in China. ${ }^{208}$ In light of these efforts, one might wonder whether any profit-maximizing studio would ever produce or release another film like Kundun. ${ }^{209}$

\section{F. Censor Dot Com}

When the digital divide first caught people's attention, it was focused on the inequalities of technological resources, such as phone lines, computer hardware, network connections, and information technology skills. As time passes, however, policymakers and scholars have expanded the definition of the digital divide to cover the disparity of accessible Internet content.

Today, "the [United States]'s most widespread news, commentary, and daily entertainment are controlled by six firms that are among the world's largest corporations, two of them foreign."210 Driven by politico-socio-economic interests, these corporations may try to decide what people will read, see, and hear (as well as what people will not) ${ }^{211}$ In such an arguably oligopolistic environment, these media giants would unlikely have incentives to compete and innovate. Rather, they might focus on their bottom line $^{212}$ and ignore the interests of the general public. ${ }^{213}$ Even

208 See id.

209 See id. (arguing that "Disney, and any other firm that is attempting to maximize profit, will never again produce a film like Kundun concerning China").

210 Bagdikian, supra note 65, at viii. These six firms are General Electric, Viacom, Disney, Bertelsmann, Time Warner, and News Corp. Bertelsmann is based in Germany, while Murdoch's News Corp. is based in Australia. Following these firms closely are: Sony, a Japanese hardware firm; Seagram's, a Canadian liquor firm; and AT\&T. See id. at x. Although these media giants are commonly referred to as the "Big Six," the power and influence of these companies are far more dominant than their name suggests. As Dean Bagdikian pointed out, these six firms "are intertwined: they own stock in each other, they cooperate in joint media ventures, and among themselves they divide profits from some of the most widely viewed programs on television, cable, and movies." Id. at xii. The power and influence of these corporations may increase further as they ponder similar arrangements following AOL. Time Warner's successful merger. See id. at xi (arguing that the AOL Time Warner merger "is likely to force other giant media firms, like Disney, Viacom, and News Corp, to make similar mergers with Internet and communication giants like Microsoft, AT\&T, and MCI World, affecting commonly known cyber operations like Yahoo, Amazon.com, and eBay.").

211 See $i d$. at xii (noting that " $[\mathrm{n}]$ ews reporting and commentary controlled by mainstream media companies are the most politically narrow in the democratic world"); $i d$. (citing a survey showing that mainstream media companies have ignored the political interests and concerns of close to a third of American voters); $i d$. at xxxviii (describing how German sociologist and writer Hersch Fischler could not get his findings about Bertelsmann's Nazi past published in Germany due to the conglomerate's influence in the country); McChesney, supra note 62, at xv (listing "Thou Shalt Not Cover Big Local Companies and Billionaires Critically" as the Eleventh Commandment in the commercial news media).

212 See McChesney, supra note 62, at 15-77 (describing the implications of hypercommercialism in the U.S. media system).

213 One of the casualties of media concentration is the quality of foreign news. See 
worse, to protect their stranglehold of the market, they might aggressively lobby the government to enact legislation that will favor themselves and oftentimes counter the interests of the general public. ${ }^{214}$

Consider the Internet for example. When the medium was first developed, many believed that the Internet and new communications technologies will strengthen democracy and increase political participation. ${ }^{215}$ In the district court opinion of Reno $v$. $A C L U$, Judge Stewart Dalzell described the Internet as "the most participatory form of mass speech yet developed."216 At that time, the cyberculture "tended to be slightly more liberal toward equal rights, less supportive of traditional lifestyles and families, more interested in government and public affairs, with stronger than average levels of political efficacy."217

BAGDIKIAN, supra note 65, at xxix. As a veteran correspondent lamented, "International news coverage in most of America's mainstream papers has almost reached the vanishing point. Today, a foreign story that doesn't involve bombs, natural disasters, or financial calamity has little chance of entering the American consciousness." Peter Arnett, Goodbye, World, Am. Journ. Rev., Nov. 1998, at 50. Another casualty is the decline in foreign films in U.S. motion picture theaters.

In the mid-1970s, foreign films accounted for over 10 percent of the box office at U.S. theaters. Every decent-sized city had one or more theaters specializing in foreign films, and Manhattan alone had two dozen such theaters. By the mid-1980s the percentage of box office accounted for by foreign films was around 7 percent, and by the late $1990 \mathrm{~s}$ it is down to under .5 percent. By the logic of the "give the people what they want" thesis, this development would reflect the fact that the American people decided that they were no longer interested in seeing non-U.S. films. But it was nothing like that at all. Instead, what this reflected was the rise to dominance in the United States of the chainowned megaplex movie theaters. With far lower costs, these multiscreen cinemas drove nearly all the one-screen theaters out of business, the very theaters that had specialized in foreign fare. Megaplex chain theaters would only grant screens to foreign films if the filmmakers were as willing to devote massive amounts to U.S. marketing as U.S. studios could, something wholly unrealistic for them to do. As a result foreign films stopped being exhibited and a new generation has come along with no idea that foreign films even exist.

MCCHESNEY, supra note 62 , at 33-34.

214 See Bagdikian, supra note 65, at viii ("The country's largest media giants have achieved alarming success in writing the media laws and regulations in favor of their own corporations and against the interests of the general public."); $i d$. at xliii (noting that "no citizen action group has the money to match the private corporate funds that flood the American political system").

215 See Lawrence K. Grossman, The Electronic Republic: Reshaping Democracy in THE INFORMATION AGE 3 (Penguin Books 1995) (arguing that the Internet and new communications technologies will "increase[e] the people's day-to-day influence on the decisions of state"); CASS Sunstein, Republic.COM 168 (2001) ("New technologies create extraordinary and growing opportunities for exposure to diverse points of view, and indeed growing opportunities for shared experiences and substantive discussions of both policy and principle.").

216929 F. Supp. 824, 883 (E.D. Pa. 1996), affd, 521 U.S. 844 (1997); see also Chester \& Larson, supra note 180 (arguing that the Internet may provide a viable platform for diversity and competition).

217 Norris, supra note 1, at 201 (citing Richard Davis \& Diana Owen, New Media and American Politics 167 (1998)); see also MCChesney, supra note 62, at 129 ("As recently as 
However, by the mid-1990s, the Internet became "colonized" by corporate interests. ${ }^{218}$ As one commentator put succinctly, "the pioneering and cooperative spirit of alternative politics characteristic of the chat rooms, bulletin boards, and MUDs found in the university community of online users in the early 1990s may have been overtaken by a more commercially dominant corporate-interest shopping-mall Web of eBay and Amazon.com today." 219 Indeed, AOL Time Warner currently controls a third of all user time spent online, and Microsoft and Yahoo increases the total share of the top three Internet content providers up to an alarming fifty percent or more. ${ }^{220}$ Small wonder commentators cautioned us when AOL proposed its merger with Time Warner, Inc.: "If you believe that the Internet is the greatest explosion of free expression and cultural resources of the past century, what happens when it is merchandised as a mass-market product by the biggest corporations in history?"221

With increasing deregulation on Capitol Hill and rapid deployment of broadband technologies, the situation may worsen. Without appropriate and adequate government intervention or industry self-regulation, the Internet likely may be transformed into "cable's closed marketplace of subscription, pay-per-view, and pre-

the early 1990 s, cyberspace was a largely noncommercial preserve, with notable egalitarian and almost anarchistic characteristics, chock full of hackers flaming the efforts of those who dared bring commerce to the Net.").

218 See Bacdikian, supra note 65, at xiii (noting that "the individual's private Internet space is continually invaded by electronic sales pitches"); Mike GodwIN, CYBER RIGHTs: Defending Free Speech in the Digtal Age 15 (Times Books 1998) (expressing nostalgia for the Internet in the early stage, when "virtual communities promise to restore to Americans at the end of the twentieth century what many of us feel was was [sic] lost in the decades at the beginning of the century-a stable sense of community, of place"); MicHAEL Margolis \& David Resnick, Politics as Usual: The Cyberspace "Revolution" (2000) (arguing that politics on the Internet is "politics as usual" conducted mostly by familiar parties, candidates, interest groups, and the news media); see also REPORT OF THE FIRST WIPO InTERnet Domain Name Process, supra note 51, II 45-49, at 17 (describing the changing nature of the Internet and how it has become "a vital new medium for an expanding digital marketplace").

Ironically, the Internet was created by government contractors using public funds. As Robert McChesney pointed out, "[t]he Internet could have never been produced by the private sector; not only would the long-term wait for a payoff have been unacceptable but the open architecture would have made no sense for a capitalist to pursue, since it makes 'ownership' of the Internet and profitability much more difficult." MCCHESNEY, supra note 62 , at 129 .

219 NORRIs, supra note 1, at 201-02.

220 See Chester \& Larson, supra note 180.

221 Rich, supra note 69; see also Yochai Benkler, Overcoming Agoraphobia: Building the Commons of the Digitally Networked Environment, 11 HARv. J.L. \& TECH. 287, 297 (1998) (arguing that "there are good reasons in terms of democratic values to support the development of a significant component of our information infrastructure that is free of centralized control by any body, governmental or commercial"). 
mium services."222 Indeed, there is an increasing concern that media conglomerates and their affiliates may "run their fast Internet wires like private toll roads, banning other Internet providers or diverting them to slow and bumpy traffic lanes." ${ }^{223}$ Under this scenario, the Internet will never reach its full potential. ${ }^{224}$

When the problem is examined from the supply side, it becomes even more complicated. The Internet has a capacity to facilitate two-way communications. Yet, many industry players are building networks that primarily focus on users as consumers, rather than producers, of content. Thus, although consumers are able to access information commodities, they do not have an equal means to produce information. ${ }^{225}$ A good example is the asymmetrical bandwidth access prevalent in most broadband Internet services, which allow users to download content with lightning speed, yet place severe limitation on the speed at which consumers can upload information to the network. Such asymmetry enables producers to use the network capacity to send information to the users, while constraining the users' ability to serve as content producers. ${ }^{226}$ In the end, the distance between consumers and pro-

222 Chester \& Larson, supra note 180.

223 Rich, supra note 69; see also Lawrence Lessig, The Future of Ideas: The Fate of the Commons in a Connected World 161 (2001) [hereinafter Lessig, Future of Ideas] (noting the trend toward control and discrimination as the Internet is moved to broadband platforms). For discussions of open access issues concerning broadband Internet services, see $i d$. at 147-176; Steven A. Augustino, The Cable Open Access Debate: The Case for a Wholesale Market, 8 Geo. Mason L. Rev. 653 (2000); Earl W. Comstock \& John W. Butler, Access Denied: The FCC's Failure to Implement Open Access to Cable as Required by the Communications Act, 8 Commlaw Conspectus 5 (2000); Mark Cooper, Open Access to the Broadband Internet: Technical and Economic Discrimination in Closed, Proprietary Networks, 71 U. Colo. L. Rev. 1011 (2000); Barbara S. Esbin \& Gary S. Lutzker, Poles, Holes and Cable Open Access: Where the Global Information Superhighway Meets the Local Right-of-Way, 10 CommLaw Conspecrus 23 (2001); Harold Feld, Whose Line Is It Anyway? The First Amendment and Cable Open Access, 8 CommLaw Conspectus 23 (2000); Rosemary C. Harold, Cable Open Access: Exorcising the Ghosts of "Legacy" Regulation, 28 N. Ky. L. REv. 721 (2001); Raymond Shih Ray Ku, Open Internet Access and Freedom of Speech: A First Amendment Catch-22, 75 Tul. L. Rev. 87 (2000); Mark A. Lemley \& Lawrence Lessig, Open Access to Cable Modems, 22 WhitTier L. Rev. 3 (2000); Daniel L. Rubinfeld \& Hal J. Singer, Open Access to Broadband Networks: A Case Study of the AOL/Time Wamer Merger, 16 BERKELEY TECH. L.J. 631 (2001); James B. Speta, Handicapping the Race for the Last Mile?: A Critique of Open Access Rules for Broadband Platforms, 17 YAle J. ON REc. 39 (2000); James B. Speta, The Vertical Dimension of Cable Open Access, 71 U. Colo. L. Rev. 975 (2000).

224 See Chester \& Larson, supra note 180 ("If our only media policy is enthusiastically pro-consolidation, it is unlikely that this new technology will ever achieve its real potential." (quoting Mark Cooper, Research Director, Consumer Federation of America)).

225 See Colby, supra note 40, at 126 (criticizing the digital divide debate for its bias toward "creating consumers of information commodities," as compared to "increasing consumer access to the means of producing information").

226 See id. at 159 (arguing that asymmetrical broadband access makes access to information services "less hospitable to the production of content by users"); see also Lewis, supra note 122, at G1 (describing the discrepancies between speeds for uploading and downloading content via broadband Internet services). 
ducers will grow wider, ${ }^{227}$ and consumers will become "end-users" in its most literal sense, i.e., "a terminus for network content-the point where the products of the 'network-of-networks' disappear in consumption." 228

Traditionally, antitrust laws have been used to break up anticompetitive alliances and mergers such as today's media giants. ${ }^{229}$ As Eben Moglen wrote, "[f]ifty years ago it was uncontroversial for the federal government to bring dozens of lawsuits reshaping the structure of the motion picture industry in order to prevent a few production studios from also controlling film distribution and exhibition."230 However, as Congress and government agencies increasingly tolerate conglomerates and monopoly and as politicians increasingly rely on corporate funds to finance their political campaigns, ${ }^{231}$ antitrust actions have become increasingly unpopular as a remedy to media concentration. Without antitrust actions, policymakers might have to turn to other measures to protect the interests of the general public.

\section{G. En@ losure of the Public Domain}

As information becomes increasingly privatized, affordable public information might become hard to obtain. ${ }^{232}$ To illustrate the danger of enclosure of the public domain, this section discusses the Sonny Bono Copyright Term Extension Act, the Digital Millennium Copyright Act, and the proposed, yet unadopted database protection legislation.

In 1998, Congress passed the Sonny Bono Copyright Term Extension Act, ${ }^{233}$ which extended the copyright term for twenty addi-

227 See Colby, supra note 40 , at 131 .

$228 \mathrm{Id}$. at $128 \mathrm{n} .22$; see also id. (arguing that the term "end-user" is "a pejoration of the netizen").

229 See Robert H. Lande, Antitrust and the Media-II, NATion, May 22, 2000, at 5 (arguing that antitrust laws were meant to address the type of concentrated power present in the commercial media); Eben Moglen, Antitmust and American Democracy, Nation, Nov. 30, 1998, at 11 (noting that application of antitrust laws to the corporate media system would be appropriate if those laws are construed as they were originally drafted and enacted).

230 Moglen, supra note 229, at 11.

231 See BAGDIKIAN, supra note 65, at xlii (noting that the telecommunications industry is "the fourth largest contributor to political campaigns"); Moglen, supra note 229, at 11 (describing the existing political system as "corruptly dependent on 'gifts' from individual and corporate wealth to elected officials and political parties").

232 See supra text accompanying notes 64-66; see also Hammond, Telecommunications Act, supra note 47, at 184-85 (arguing that the privatization of information has made travel in the information superhighway as unaffordable as many vacation excursions).

23317 U.S.C. $\$ 304(2000)$. For discussions and criticisms of copyright term extension, see generally Robert L. Bard \& Lewis Kurlantzick, Copyright Duration: Duration, term Extension, the European Union and the Making of Copyright Policy (1999); Michael H. Davis, Extending Copyright and the Constitution: "Have I Stayed Too Long?", 52 FlA. L. REv. 989 (2000); Jane C. Ginsburg, Copyright Legislation for the "Digital Millennium," 23 Colum.-VL.A 
tional years. ${ }^{234}$ To some extent, this extension was expected, as Congress "has extended the term of subsisting copyrights eleven times in the past forty years." 235 Nonetheless, the extension receives noticeable attention as the Internet brings copyright issues closer to the lives of the general public and as the cyberworld offers an attractive alternative model for dissemination of information. As Professor Lawrence Lessig said poignantly in his new book, The Future of Ideas, if every creative act reduced to a tangible medium of expression is protected for upward of 150 years, whether or not the protection benefits the author, the work will fall into "a copyright black hole, unfree for over a century." 236 Most recently, the United States Supreme Court granted certiorari in a case challenging the constitutionality of the Sonny Bono Copyright Term Extension Act. ${ }^{237}$

Another piece of legislation that has drawn widespread notoriety is the Digital Millennium Copyright Act ("DMCA"), ${ }^{238}$ which Congress enacted in the same year as they extended the copyright

J.L. \& ARTs 137, 170-75 (1999) [hereinafter Ginsburg, Copyright Legislation]; Marci A. Hamilton, Copyright Duration Extension and the Dark Heart of Copyright, 14 CARDozo ARTS \& ENT. L.J. 655 (1996); Peter A. Jaszi, Goodbye to All That-A Reluctanl (and Perhaps Premature) Adieu to a Constitutionally-Crounded Discourse of Public Interest in Copyright Law, 29 VAND. J. Transnat'L L. 595 (1996); Dennis S. Karjala, The Term of Copyright, in Growing Pains: Adapting Copyright for EDUCATION and Society (Laura N. Gasaway ed., 1997); Neil Weinstock Netanel, Locating Copyright Within the First Amendment Skein, 54 Stan. L. Rev. 1, 70-74 (2001); William F. Patry, The Copyright Term Extension Act of 1995: Or How Publishers Managed to Steal the Bread from Authors, 14 CARDozo ARTs \& ENT. L.J. 661 (1996); Symposium, The Constitutionality of Copyright Term Extension: How Long Is Too Long, 18 CARDozo ARTs \& ENT. L.J. 651 (2000); J.H. Reichman, The Duration of Copyright and the Limits of Cultural Policy, 14 Cardozo Arts \& Ent. L.J. 625 (1996); Edward C. Walterscheid, Defining the Patent and Copyright Term: Term Limits and the Intellectual Property Clause, 7 J. Intell. Prop. L. 315 $(2000)$.

234 See 17 U.S.C. $\$ 304$.

235 Lessig, Future of IdeAs, supra note 223, at 197.

236 Id. at 251.

237 On February 19, 2002, the United States Supreme Court granted certiorari in Eldred v. Reno, in which the constitutionality of the Sonny Bono Copyright Term Extension Act is challenged. For a collection of briefs and other legal documents concerning Eldred, see Openlaw: Eldred v. Ashcroft, at http://eon.law.harvard.edu/openlaw/eldredvashcroft/. See also Marci Hamilton, Bringing the People into the Copyright Arena: How the New Awareness of Copyright Law Issues Can Help in Guarding the Public's Domain, FindLaw's WRIT: LeGal. ComMENTARY, at http://writ.news.findlaw.com/hamilton/-20010329.html (Mar. 29, 2001) [hereinafter Hamilton, Bringing the People into the Copyright Arena] for a discussion of the difficulties of the Eldred litigation.

238 Pub. L. No. 105-304, 112 Stat. 2860 (1998) (codified as amended in scattered sections of 17 U.S.C.). Professor Jessica Litman criticized the DMCA as follows:

The DMCA is long, internally inconsistent, difficult even for copyright experts to parse and harder still to explain. Most importantly, it seeks for the first time to impose liability on ordinary citizens for violation of provisions that they have no reason to suspect are part of the law, and to make noncommercial and noninfringing behavior illegal on the theory that that will help to prevent piracy. Jessica Litman, Digital Copyright 145 (2001). See generally Ginsburg, Copyright Legislation, supra note 233, at 137-171 for a comprehensive discussion of the DMCA. 
term. DMCA is problematic on two counts. First, it requires Internet service providers to remove any hosted content that allegedly infringes upon the work of a copyright holder, regardless of whether the reproduction of materials is permissible under existing copyright law. ${ }^{239}$ Second, it prohibits the circumvention of anticopying devices and rights-management systems, thus preventing people from engaging in actions that traditionally have been considered fair use. ${ }^{240}$ Since the enactment of the DMCA, commentators have widely criticized the statute for stifling creativity. ${ }^{241}$ So far, challenge to the constitutionality of the anticircumvention provision of the DMCA has failed. ${ }^{242}$

The final piece of legislation that sparked major controversies concerns protection of nonoriginal databases. Shortly after the European Union promulgated its Database Directive in $1996,{ }^{243}$ many legislative proposals on database protection surfaced in Con-

239 See 17 U.S.C. $\$ 512$.

240 See id. $\$ 1201$.

241 Shortly after the United States Copyright Office released its report on the effects of the DMCA, U.S. Copyright Office, Study Required by Section 104 of The Digital MiLLENNIUM COPYRIGHT ACT (2001), available at http://www.loc.gov/copyright/reports/studies/-dmca/dmca_study.html, more than fifty intellectual property law scholars expressed disappointment over the report and urged Congress to conduct its own study. See IP Law Professors Urge Congress to Do Its Own DMCA Siudy, Wash. InTERnet Daily, Oct. 16, 2001, at 200. The study is required by section 104 of the DMCA.

242 For a recent unsuccessful challenge of the DMCA, see Universal City Studios, Inc. v. Corley, 273 F.3d 429 (2d Cir. 2001) (affirming the district court decision that enjoined the defendant publisher from posting DeCSS program on his website and from knowingly linking the site to any other website on which that program is posted). In July 2001, Russian cryptographer Dmitry Sklyarov was arrested in the United States after giving a presentation to a large convention of computer hackers on the software that removed security protection from Adobe e-books. He became the first person to be charged with violating the DMCA. After strong protests in the United States, he was released in a deal that "saw him admit the facts of the case but not any illegal activity." David Frith, A Promotion a Day Keeps Apple A-weigh, Canberra Times, Jan. 7, 2002, at A12; see Jennifer Lee, U.S. Arrests Russian Cryptographer as Copyright Violator, N.Y. Times, July 18, 2001, at C8 (reporting Sklyarov's arrest); Complaint, U.S. v. Sklyarov (N.D. Cal. July 7, 2001) (No. 501 257), available at http:/ /www.eff.org/IP/DMCA/US_v_Sklyarov/20010707_complaint.html.

243 Council Directive 96/9, 1996 O.J. (L 77) 20. For discussions of the EU Database Directive and recent development concerning U.S. database legislation, see Yochai Benkler, Constitutional Bounds of Database Protection: The Role of Judicial Review in the Creation and Definition of Private Rights in Information, 15 BERkELEY TECH. L.J. 535 (2000) [hereinafter Benkler, Constitutional Bounds]; Jane C. Ginsburg, Copyright, Common Law, and Sui Generis Protection of Databases in the United States and Abroad, 66 U. Cin. L. Rev. 151 (1997) [hereinafter Ginsburg, Copyright, Common Law]; Marci A. Hamilton, A Response to Professor Benkler, 15 Berkeley TeCH. L.J. 605 (2000); Malla Pollack, The Right to Know?: Delimiting Database Protection at the Juncture of the Commerce Clause, the Intellectual Property Clause, and the First Amendment, 17 Cardozo ArTs \& ENT. L.J. 47 (1999); J.H. Reichman \& Paul F. Uhlir, Database Protection at the Crossroads: Recent Developments and Their Impact on Science and Technology, 14 Berkeley Tech. L.J. 793 (1999); Peter K. Yu, Evolving Legal Protection for Databases, GigaLaw.COM, at http://www.gigalaw.com/articles/2000/yu-2000-12.html (Dec. 2000); see also Charles R. McManis, Intellectual Property and International Mergers and Acquisitions, $66 \mathrm{U}$. CIN. L. REv. 1283, 1294-95 (1998) (discussing the tension between the EU Database Directive and the TRIPs Agreement). 
gress. ${ }^{244}$ Despite this large number of proposals, Congress has yet to adopt any database legislation. There are various reasons. ${ }^{245}$ As notable intellectual property scholars pointed out, sui generis database protection would confer far broader and stronger exclusive rights on database content than is necessary to provide the needed incentives for database producers. ${ }^{246}$ Such protection also would raise serious constitutional questions under the Commerce Clause, the Copyright Clause, and the First Amendment. ${ }^{247}$ Moreover, sui generis protection may be unnecessary in light of the significant protection currently enjoyed by database producers under state contract and misappropriation laws and nonlegal, technological protective devices. ${ }^{248}$ In fact, many database producers, which are also database users, would unlikely support any legislation unless they are certain that the legislation has struck the right balance

\footnotetext{
244 Such legislation include, to name a few, Collections of Information Antipiracy Act of 1999, H.R. 354, 106th Cong. (1999); Collections of Information Antipiracy Act, H.R. 2652, 105th Cong. (1998); Consumer and Investor Access to Information Act of 1999, H.R. 1858, 106th Cong. (1999); Database Investment and Intellectual Property Antipiracy Act of 1996, H.R. 3531, 104th Cong. (1996).

245 See sources cited supra note 243 for criticism of past legislative proposals on database protection. See also Marci Hamilton, Should U.S. Intellectual Property Rights Change to Fit World Norms?, FindLaw's Writ: Legal Commentary, at http://writ.news.findlaw.com/hamilton/20010524.html (May 24, 2001) (arguing that the United States should not yield easily to global pressure without considering the strengths of its intellectual property system).

246 By granting database producers a monopoly over their collected data, the legislative proposals would allow private entities to lock up information that is essential to basic scientific research and future creative endeavors. See Reichman \& Samuelson, supra note 64, at 113-24 (discussing the adverse impact of sui generis database protection on scientific research and education); Reichman \& Uhlir, supra note 243, at 796-821 (discussing the adverse impact of database protection laws on scientific, technical, and educational users of factual data and information). The proposals also would create an anti-competitive environment that makes it difficult for valued-added products and services to enter the market, thus making information products more expensive. See Benkler, Constitutional Bounds, supra note 243 , at $562-65$ (discussing the anti-competitive nature of database protection laws); Reichman \& Samuelson, supra note 64, at 124-30 (discussing how sui generis database protection would frustrate competition in the market for value-added products and services).

247 See Benkler, Constitutional Bounds, supra note 243, at 539-57 (discussing the constitutional limits of Congress's power to create exclusive private rights in information); Hamilton, A Response to Professor Benkler, supra note 243, at 619-28 (discussing the constitutional deficiencies of U.S. database legislation); Pollack, supra note 243, at 50-89 (discussing the constitutional constraints on database protection); see also Paul J. Heald, The Extraction/ Duplication Dichotomy: Constitutional Line-drawing in the Database Debate, 62 OHIо Sт. L.J. 933, 935 (2001) (arguing that Congress "could rely on the Commerce Clause to grant thin protection to unoriginal collections of information, but is constitutionally constrained from prohibiting the extraction and use of facts contained in a compilation, regardless of whether the compilation is original").

248 See Jonathan Band \& Makoto Kono, The Database Protection Debate in the 106th Congress, 62 Onо St. L.J. 869, 869-70 (2001); Ginsburg, Copyright, Common Law, supra note 243, at 176; see also eBay, Inc. v. Bidder's Edge, Inc., 100 F. Supp. 2d 1058 (N.D. Cal. 2000) (recognizing claims of "trespass to chattels" over the unauthorized extraction of information from an Internet website); NBA v. Motorola, 105 F.3d 841 (2d Cir. 1997) (prohibiting copying of "hot news" or time-sensitive materials for competition purposes).
} 
between the production of databases and the use of collected information..$^{249}$

In the past two centuries, the copyright industries have been very successful in protecting their property and in expanding their control over creative expressions in new media. ${ }^{250}$ However, this dynamic has shifted as the American public becomes increasingly aware of copyright issues and how those issues would affect the quality of their lives. ${ }^{251}$ Indeed, in recent years, the public has increasingly embraced arguments advocating the protection of the public domain. ${ }^{252}$ Perhaps the digital divide may provide just another reason why such protection is badly needed.

\section{H. The Digital Me $e^{253}$}

Government, media conglomerates, and the copyright indus-

$249 \mathrm{Yu}$, Evolving Legal Protection for Databases, supra note 243. So far, the database industry has failed to provide substantial factual information as to how it would be harmed had the legislative proposal not been adopted. It only succeeded in making generalized claims of potential foreign competition and piracy in the European markets. See Benkler, Constitutional Bounds, supra note 243, at 591-92; Reichman \& Samuelson, supra note 64, at 70; see also Pollack, supra note 243, at 92-93 (noting that the American database industry is booming). These claims ring hollow when only one, McGraw Hill, out of the three major database industry stakeholders is an American company. See Benkler, Constitutional Bounds, supra note 243, at 592. Reed Elsevier is a European Company, and Thompson is a Canadian company.

250 See LITMAN, supra note 238 (describing the success of the copyright industries in lobbying for legislation that protects their business interests); SIVA VAIDHYANATHAN, Corvrights and Copywrongs: The Rise of Intellectual Property and How It Threatens CREATIVITY (2001) (tracing the historical development of copyright laws; Jessica D. Litman, Copyright, Compromise, and Legislative History, 72 Cornell L. Rev. 857, 862 (1987) (arguing that the legislative history of the 1976 Copyright Act reflects "an anomalous legislative process designed to force special interest groups to negotiate with one another"); Stewart E. Sterk, Rhetoric and Reality in Copyright Law, 94 MicH. L. Rev. 1197 (1996) (arguing that American copyright protection expands as a result of interest group politics and the need for the nation's elite to protect the status quo).

251 See Hamilton, Bringing the People into the Copyright Arena, supra note 237 (noting that the increasing public awareness of copyright issues that has resulted from the Napster, MP3.com, and Microsoft legal battles might change the dynamics of intellectual property lawmaking).

252 Examples of recent literature emphasizing the importance of the public domain and the danger of its disappearance include: LESSIG, FuturE of IDEAS, supra note 223 (lamenting how the media and software industries are stifling innovation in the New Economy); LITMAN, supra note 238 (showing how the increased domination of interest groups in the lawmaking processes has made copyright law anti-public and incomprehensible); VAIDHYANATHAN, supra note 250 (describing how the increasing corporate control over the use of software, digital music, images, films, books and academic materials has steered copyright law away from its original design to promote creativity and cultural vibrancy); Yochai Benkler, Free as the Air to Common Use: First Amendment Constraints on Enclosure of the Public Domain, 74 N.Y.U. L. Rev. 354 (1999) (advocating the use of Justice Brandeis's conception that information should be "free as the air to common use" as a conceptual baseline to limit property rights in information products). For earlier discussions, see David Lange, Recognizing the Public Domain, 44 Law \& Contemp. Probs. 147 (1981); Jessica Litman, The Public Domain, 39 EMOrY L.J. 965 (1990).

253 Nicholas Negroponte of the Massachusetts Institute of Technology Media Lab 
tries are not the only censors on the Internet. With the increasing filtering capabilities of digital tools, we easily could shut ourselves out of information that challenges our beliefs, worldviews, and philosophies.

In his recent book, Republic.com, ${ }^{254}$ Professor Cass Sunstein discussed at length the danger of unlimited filtering by new communications technologies. As he pointed out, "[t]echnology has greatly increased people's ability to 'filter' what they want to read, see, and hear." 255 With a few "points and clicks," people can design newspapers and magazines that are specially customized to their individual tastes and viewpoints. As a result, they "need not come across topics and views that [they] have not sought out. Without any difficulty, [they] are able to see exactly what [they] want to see, no more no less." 256

According to Professor Sunstein, a market dominated by countless versions of "The Daily Me" would pose danger to democracy and self-government, thus compromising individual freedom..$^{257}$ Such a market also would fragmentize society ${ }^{258}$ and undermine social stability. ${ }^{259}$ Even worse, as people tend to make choices that do not disturb their existing worldviews, ${ }^{260}$ the increased group polarization caused by the ability of digital technologies to customize may lead to extremism and violence. ${ }^{261}$

introduced the term "The Daily Me." Nicholas Negroponte, Being Digrtal 153 (Vintage Books 1995).

254 SUNSTEIN, supra note 215.

255 Id. at 3.

256 Id.

257 See id. at 192. Contra Grossman, supra note 215, at 3-4 (arguing that new communications technologies transform the United States into an electronic republic that enables people to take a more direct role in government than the Framers have intended); NorRIS, supra note 1, at 19 (arguing that digital politics may level the playing field for transnational advocacy networks, alternative social movements, protest organizations, and minor parties); Rheingold, supra note 135, at 4 (arguing that new communications technologies "can help grassroots political organizations, nonprofit groups, and other public interest groups to gather critical information, organize political action, sway public opinion and guide policy-making").

258 See Sunstein, supra note 215, at 192; see also Marshall Van Alstyne \& Erik Brynjolfsson, Electronic Communities: Global Village or Cyberbalkans, at http://web.mit.edu/marshall/www/ papers/CyberBalkans.pdf (Sept. 20, 1996) (discussing how information technology has "the potential to fragment communities by leading people to spend more time on special interests while screening out less preferred contact").

259 See Sunstein, supra note 215, at 194.

$260 \mathrm{See}$ id. at 57 (noting the existence of "a natural human tendency to make choices, with respect to entertainment and news, that do not disturb our preexisting view of the world").

261 See id. at 199; see also Cass R. Sunstein, Deliberative Trouble? Why Croups Go to Extremes, 110 YALE L.J. 71 (2000) (examining the impact of group polarization on deliberation in a heterogeneous democratic society). As Sunstein explained, "[A]Il too often, those most in need of hearing something other than echoes of their own voices are least likely to seek out alternative views." SunSTE1N, supra note 215, at 199. 
Despite Sunstein's forceful arguments and numerous supporting illustrations, one might wonder why most of us would be so uncurious, narcissistic, close-minded, and ignorant of our need for diverse opinions and competing viewpoints. ${ }^{262}$ One also might wonder why most of us would not have different interpretations or draw different conclusions when we see a similar version of "The Daily Me." After all, as Sunstein illustrated with his example of Israel's policy of having one broadcast channel, shared experiences are effective in promoting a democratic exchange of ideas. ${ }^{263}$

Nevertheless, despite these queries (as well as other disagreements concerning his belief in the role of government in speech regulation), Professor Sunstein has alerted us to the danger of unlimited filtering and customization by new communications technologies. Because the digital divide concerns the availability of relevant content, unlimited filtering capabilities of digital technologies might widen this divide by allowing people to "customize" themselves out of the content needed to make informed judgment and rational decisions.

\section{The Market of Privacy}

In recent years, companies have offered computer equipment, Internet hookups, and server storage space free of charge in exchange for the user's personal and profile information, Web surfing habits, and purchasing preferences, which were subsequently sold to advertisers, marketers, and demographic researchers. ${ }^{264}$

262 Even Professor Sunstein conceded, " $[\mathrm{m}]$ ost of us have a great deal of curiosity, and sometimes we like to see materials that challenge us and that do not merely reinforce our existing tastes and judgments. This is demonstrated every day, not least by the truly astonishing growth of sites on the Internet." Id. at 200; see also Gary Chapman, Cyberfunk, WaSH. Post, June 10, 2001, at T4 (criticizing Sunstein's book for being "disconnected from the real world" and noting that the Internet is "the world's greatest and most amazing source of surprising information"); Neil Seeman, Democracy.com, NAT'L Rev. Online, at http:// www.nationalreview.com/weekend/books/books-seeman061601.shtml (June 16, 2001) (criticizing Sunstein's book for "invent[ing] a problem that doesn't exist").

263 See Sunstein, supra note 215, at 92-93 (discussing how Israel's one-channel policy "can be extremely valuable from the democratic point of view").

264 See Maier, supra note 12, I 23 (noting that free computers and free Internet access are provided in exchange for "the consumer's personal and market demographic data; acceptance of continuous advertising on screen; permission to track, record, and disseminate to participating advertisers the Internet activity of the consumer; and an agreement that the consumer will participate in a certain minimum number of hours per month on the Internet"); see also Jefrrey Rosen, The Unwanted Gaze: The Destruction of Privacy IN AmERICA 159-195 (Vintage Books 2001) (discussing privacy issues in cyberspace); Kathryn Balint, The Cost of 'Free' Stuff, SAN Diego Union-Trib., Feb. 1, 2000, at 6 (discussing the costs of having free computers and Internet access); Phillip Robinson, Free Internet Provider May Carry a Price, Dallas Morning News, Oct. 12, 2000, at 2F (discussing the concerns for privacy invasion by free Internet service providers). In addition to privacy invasion, users of free Internet service face other problems such as slow connections, repeated busy signals, a tendency to lose connections in mid-session, and an annoying display 
For example, Free-PC offered free hardware and software to the American public, ${ }^{265}$ while Juno and NetZero provide free Internet access to consumers. ${ }^{266}$

Although these offerings may allow the needy to have the essential tools needed to participate in the digital economy, one might wonder whether it is ethical for these companies to barter computers and online access for privacy. To many consumer advocates, these offers are "Faustian bargains" that take advantage of those who are on the unfortunate side of the digital divide. ${ }^{267}$ In-

of banner ads. Michael A. Hiltzik, Free Internet Providers Are Making Inroads, L.A. TIMEs, Jan. 21,2000 , at NAl. Since the dot-com crash, fewer companies offer free Internet service as Internet advertising declined. See Dave Peyton, Internet Service Deals Hard to Find, but Exist, CHI. TRIB., Dec. 17, 2001, at 8.

265 See Karen Kaplan, In Giveaway of 10,000 PCs, the Price Is Users' Privacy, L.A. Times, Feb. 8, 1999, at A1 (reporting privacy concerns for the Free-PC offer); Adrian Peracchio, The Private Domain / That Free-Computer Offer Is a Faustian Bargain, NEwsDaY, Mar. 11, 1999, at A50 (criticizing free computer offer as "a Faustian bargain"); Iris Schneider, Free-computer Offering Has a Hidden Cost, CHI. Sun-Times, Feb. 9, 1999, at 42 (discussing the hidden costs of the Free-PC offer); Jeffrey Rosen, The Eroded Self, N.Y. Times, Apr. 30, 2000, at A46 (compared the Free-PC deal to "allowing a camera into your bedroom in exchange for a free toaster"); see also Maier, supra note 12, II 24 (describing Free-PC's services and consumers' concern that the company might "market this service to only those in demographics that are likely to purchase from the Internet"). The Free-PC offer ended after eMachines acquired the company five months after it had shipped its first 20,000 computers. See Balint, supra note 264, at 6; Lisa Guernsey, The End of Free-PC Program Is Windfall for Early Subscribers, N.Y. Times, Feb. 24, 2000, at G3; Saul Hansell, No More Giveaway Computers. Free-PC to Be Bought by eMachines, N.Y. Times, Nov. 30, 1999, at C1.

266 In September 2001, NetZero merged with Juno to form United Online. See Press Release, NetZero and Juno Complete Merger Creating United Online, (Sept. 25, 2001), available at http://www.irconnect.com/untd/pages/news_releases.shtml?d=20473. One journalist described NetZero's policy:

NetZero ... requires users to fill out a 40 -item questionnaire eliciting personal data as well as marketing habits and buying predilections. Whenever users log on, the company tracks their meanderings all over the Web and sells that information to advertisers, whose pitches appear in an on-screen window, the "ZeroPort," that users cannot close as long as they remain connected.

Hiltzik, supra note 264, at NA1. For the privacy statement issued by NetZero, see Netzero, Inc. Privacy Statement, at http://netzero.net/legal/privacy.html. Ironically, despite its collection of users' personal information, NetZero portrays itself as the "Defender of the Free World." "In an extensive advertising campaign, Netzero.com portrays its founders as besieged witnesses before a legislative committee, defending basic liberty by protecting everyone's 'right' to have access to the Internet." Sunstein, supra note 215, at 19. For privacy concerns regarding Juno, see Suzanne Choney, Juno May Not Charge, but It's No Free Lunch, San Diego Union-Trib., Mar. 27, 2001, at 2.

267 See, e.g., Peracchio, supra note 265, at A50; Schneider, supra note 265, at 42 (quoting Evan Hendricks, a privacy advocate and editor of the newsletter Privacy Times). In addition to privacy intrusion, some commentators have expressed concern about the high susceptibility of the poor to advertising. As one commentator put it, "[h] istorically, the poor are the most susceptible to advertising generally, the least able to afford to navigate the perils of our consumerist culture and the most prone to being misled by dishonest advertising." Katie Hafner, We're Not All Connected, Yet, N.Y. Times, Jan. 27, 2000, at G1 (quoting Daniel Ben-Horin, president of CompuMentor, one of the nation's largest providers of technology assistance services to nonprofit groups and schools).

Andrew Shapiro argued that the market of privacy would create a system of first-and second-class privacy rights that make the poor even more vulnerable.

The poor would be at a particular disadvantage. As companies are able to 
deed, some commentators are concerned that these bargains might create problems to which the poor, the socially under-privileged, and the less developed countries have no solutions. ${ }^{268}$ Nonetheless, with the increased protection of privacy, through legislation, ${ }^{269}$ industry self-regulation, ${ }^{270}$ and technical rules $^{271} \mathrm{~s}$ - the chances for exploiting the information have-nots may be greatly reduced.

charge increasingly higher rates for finer shades of privacy, poorer customers who can't afford these premiums will be left more exposed simply by dint of economic disadvantage. Even if the markups are small, a little added privacy may not seem worth it for those with limited disposable income, especially since they are already likely to be monitored by the state if they receive welfare benefits or live in high-crime neighborhoods.

SHAPIRO, supra note 159 , at $162-63$.

268 Tracy Cohen mentioned this point in this Symposium.

269 The European Union favors the legislative approach. See Council Directive 95/46, 1995 O.J. (L 281) 31; see also Peter K. Yu, An Introduction of EU Directive on the Protection of Personal Data, GrGaLaw.com, at http://www.gigalaw.com/articles/2001/yu-2001-07a.html (July 2001) (discussing the differences between the European and U.S. approaches to data protection). See Symposium, Data Protection Law and the European Union's Directive: The Challenge for the United States, 80 lowa L. Rev. 431 (1995), for an excellent symposium on the EU Privacy Directive.

270 Unlike the European Union, " $[t]$ he United States uses a sectoral approach that relies on a mix of legislation, regulation, and self-regulation." DEP'T OF COMMERCE, SAFE HARBOR OvERVIEw, available at http://www.export.gov/safeharbor/sh_overview.html (last visited Feb. 27, 2002); see also Julia M. Fromholz, The European Union Privacy Directive, 15 Berkeley TECH. L.J. 461, 471 (2000) (noting that the United States hold "a very different view [from the European Union] of both privacy and the role of government"); Robert M. Gellman, Fragmented, Incomplete, and Discontinuous: The Failure of Federal Privacy Regulatory Proposals and Institutions, 6 SofTware L.J. 199 (1993) (explaining why the United States failed to enact comprehensive privacy legislation); Arthur R. Miller, Personal Privacy in the Computer Age: The Challenge of a New Technology in an Information-Oriented Society, 67 Mich. L. Rev. 1089 (1969) (examining the challenges facing the development of privacy laws in the United States); Joel R. Reidenberg, Setting Standards for Fair Information Practice in the U.S. Private Sector, 80 IowA L. REv. 497, 507-11 (1995) (arguing that the American society has a "desire to disperse standards setting").

271 Professors Lawrence Lessig and Joel Reidenberg maintained that technical standards and default settings will be particularly helpful in protecting privacy in Cyberspace. See, e.g., Joel R. Reidenberg, Resolving Conflicting International Data Privacy Rules in Cyberspace, 52 Stan. L. Rev. 1315, 1331 (2000) ("Technical rules and default settings establish data privacy norms."); LESSIG, CoDE, supra note 56, at 160 (advocating the need for "a machine-tomachine protocol for negotiating privacy protections"); see also Lawrence Lessig, Reading the Constitution in Cyberspace, 45 EMORY L.J. 869, 898 (1996) (discussing the use of technology as a tool to regulate behavior and facilitate compliance with legal norms); Joel R. Reidenberg, Governing Networks and Rule-Making in Cyberspace, 45 EMORY L.J. 911, 929 (1996) ("State governments can and should be involved in the establishment of norms for network activities, yet state governments cannot and should not attempt to expropriate all regulatory power from network communities."); Joel R. Reidenberg, Lex Informatica: The Formulation of Information Policy Rules Through Technology, 76 TEx. L. Rev. 553, 555 (1998) (arguing that policymakers must "understand, consciously recognize, and encourage" the set of rules for information flows imposed by technology and communication networks known as "Lex Informatica"); Joel R. Reidenberg, Rules of the Road for Global Electronic Highways: Merging the Trade and Technical Paradigms, 6 Harv. J.L. \& TECH. 287, 296-301 (1993) (discussing the use of technology to protect the integrity and interoperability of information networks). 


\section{CONCLUSION}

The Internet and new communications technologies have caused profound changes to our society. Whether these technologies can benefit our community will depend on us (and the policymakers we elect). As a media historian put it succinctly, "[e]ach time a new medium comes along, great hopes are raised. But the lesson of history is that every new medium provides new opportunities for selling as well as for education, for monopolists as well as for democracy, and for abuse as well as for benefit." 272 Thus, it is important that we ensure that the Internet and new communications technologies become a tool of empowerment, rather than one of disenfranchisement. By doing so, we not only will bridge the digital divide, but also will create digital dividends for those who traditionally have been the information have-nots.

272 Steve Lohr, The Great Unplugged Masses Confront the Future, N.Y. TIMEs, Apr. 21, 1996, $\$ 4$, at 1 (quoting Erik Barnouw, professor emeritus at Columbia University and a media historian); see also Grossman, supra note 215, at 170 (noting that "technology by itself is inherently neither educational nor frivolous, neither empowering nor debilitating, neither uplifting nor degrading, neither democratic nor authoritarian, neither informative nor manipulative"); Hammond, Telecommunications Act, supra note 47, at 201.

Communications technology can be used to expand and equalize access to education and electronic political empowerment, or it can be used to disenfranchise the growing number of Americans who are at risk. It can be used to provide much needed efficiencies in service delivery and economic development to urban and rural communities, or it can be used to bypass and abandon Id. them. 